\title{
Acute telomere deprotection prevents ongoing BFB cycles and rampant instability in p16 $^{\text {INK4a-deficient epithelial cells }}$
}

\author{
Aina Bernal ${ }^{1}$, Marc Moltó-Abad ${ }^{1,2}$, Daniel Domínguez ${ }^{1}$ and Laura Tusell ${ }^{1}$ \\ ${ }^{1}$ Unitat de Biologia Cel-lular, Facultat de Biociències, Universitat Autònoma de Barcelona, 08193 Cerdanyola del Vallès, Spain \\ ${ }^{2}$ Current address: Unitat de Malalties Minoritàries, Hospital Universitari de la Vall d'Hebron, 08035 Barcelona, Spain \\ Correspondence to: Laura Tusell, email: laura.tusell@uab.cat \\ Keywords: MCF-10A; breast epithelial cells; chromosome instability; telomere-dysfunction; TRF2 $\triangle \mathrm{B \Delta M}$ \\ Received: June 28, $2017 \quad$ Accepted: May 13, $2018 \quad$ Published: June 05, 2018 \\ Copyright: Bernal et al. This is an open-access article distributed under the terms of the Creative Commons Attribution License 3.0 \\ (CC BY 3.0), which permits unrestricted use, distribution, and reproduction in any medium, provided the original author and source \\ are credited.
}

\section{ABSTRACT}

Telomere dysfunction drives chromosome instability through endless breakagefusion-bridge (BFB) cycles that promote the formation of highly rearranged genomes. However, reactivation of telomerase or ALT-pathway is required for genome stabilisation and full malignant transformation. To allow the unrestricted proliferation of cells at risk of transformation, we have established a conditional system of telomere deprotection in p16 ${ }^{\text {INK4a }}$-deficient MCF-10A cells with modified checkpoints. After sustained expression of a dominant negative form of the shelterin protein TRF2 (TRF2 ${ }^{\triangle B \Delta M}$ ), cells with telomere fusion did progress to anaphase but no signs of ongoing BFB cycles were observed, thus anticipating proliferation defects. Indeed, $96 \mathrm{~h}$ TRF2 ${ }^{\triangle \mathrm{B} \Delta \mathrm{M}}$ expression resulted in noticeable growth proliferation defects in the absence of cell cycle disturbances. Further transient periods of $96 \mathrm{~h}$ telomere uncapping did not result in cell cycle disturbances either. And reduction of the telomere damage to short acute deprotection periods did not in any case engender cells with a reorganised karyotype. Strikingly, the growth arrest imposed in cells showing dysfunctional telomeres was not accompanied by an activation of the DNA damage response at cellular level, or by the presence of visible markers of senescence or apoptosis. We propose that the deprotection of many telomeres simultaneously, even for a short time, results in a local activation of the cellular stress response which consequently triggers gradual cell withdrawal from cell cycle, restraining the onset of genomic instability.

\section{INTRODUCTION}

Telomeres are nucleoprotein complexes that cap the ends of chromosomes, thus preventing illegitimate recombination processes. By adopting a t-loop structure, telomeres ensure genomic stability by providing chromosome end protection [1,2, and reviewed by 3$]$. The most deleterious outcome of telomere deprotection is the formation of chromosome end-to-end fusions, which may fire breakage-fusion-bridge (BFB) cycles and rampant chromosome instability (CIN) [4-6, and reviewed by 7$]$. In certain types of epithelial cancers, telomere dysfunction is considered to be a key trigger for $\mathrm{CIN}$ and a promoter of tumourigenesis $[8,9]$. Specifically in the breast, studies support the view that telomere dysfunction can precede disease progression and is not simply a biomarker of advanced disease [10-13]. Indeed, qFISH studies have indicated modest telomere shortening occurring in hyperplasia, a more significant reduction becoming prevalent as early as ductal carcinoma in situ (DCIS) [14, 15], and the presence of significantly short telomeres in malignant breast cells compared to normal surrounding breast tissue [16]. The impact of telomeres in breast carcinogenesis is further supported by the detection of telomere-to-telomere fusion, a hallmark of telomere dysfunction, in early stage breast tumours, including DCIS [17]. 
Telomeres that can no longer exert end-protective functions because of excessive telomere attrition or alterations in the components of the shelterin complex itself, are recognised as sites of DNA damage and recruit the same repair factors that are associated with double strand breaks (DSBs) at other sites of the genome [18, 19]. Unprotected chromosome ends impinge on signalling kinases ATM and ATR to activate a DNA damage response (DDR) that via p53-p2 $1^{\text {Waf1/Cip1 }}$ or pRb-p16 $6^{\text {INK4a }}$ axis leads to checkpoint-mediated cell cycle arrest and senescence or apoptosis [20, 21]. Among the shelterin proteins, TRF2 (telomere repeat binding factor 2) is at the heart of the molecular events that maintain telomere integrity in mammals [22-24, and reviewed by 25]. TRF2 binding to DNA in vitro stimulates strand invasion, adopting structures that resemble t-loops [2]. Furthermore, the frequency of t-loops in vivo is significantly reduced in cells lacking TRF2, implicating this sheltering subunit in its formation and/or stabilisation [26]. It has been previously reported that expression of the truncated form of TRF2 $\left(\mathrm{TRF} 2^{\triangle \mathrm{B} \Delta \mathrm{M}}\right)$, which lacks the Basic and Myb domains, interferes with the accumulation of the endogenous TRF2 protein at telomeres [22]. Depletion of TRF2 in normal cells using RNAi, dominant-negative alleles or Cremediated deletion typically results in a non-reversible telomere dysfunction phenotype that induces strong DNA damage signalling and stalls cell cycle progression [19, 22, $23,27]$. Therefore, telomere dysfunction acts as a tumour suppressive mechanism in cells with a functional DDR by limiting the expansion of unstable cell populations harbouring precancerous mutations. In sharp contrast, dysfunctional telomeres in cells with a limited DDR might allow the proliferation of damaged cells at risk of transformation if telomere length is stabilised through telomerase activation or ALT-pathways.

With the aim of generating heavily rearranged but telomerase stabilised epithelial human cells, we generated a versatile experimental system of telomere deprotection where TRF $2^{\triangle \mathrm{B} \Delta \mathrm{M}}$ expression is controlled by a doxycycline inducible promoter in the non-tumorigenic epithelial mammary cell line MCF-10A. We reasoned that limiting the telomere insult to brief periods might allow for a bypass of the acute cellular responses to dysfunctional telomeres. Besides that, given that telomere dysfunction can either prevent or promote tumourigenesis depending on the intactness of the DDR system, we used different approaches to experimentally inhibit the p53/ $\mathrm{pRb}$ pathways. Our results demonstrate that, after $96 \mathrm{~h}$ of sustained TRF $2^{\triangle \mathrm{B} \Delta \mathrm{M}}$ expression, the telomere dysfunction phenotype increased with checkpoint protein inactivation, with the greatest impact seen in SV40LT transduced MCF-10A cells. However, evidence of chromosome specific structural aberrations or extensive aneuploid configurations compatible with ongoing BFB cycles were unnoticed in cells lacking p16 ${ }^{\mathrm{INK} 4 \mathrm{a}}$ only or along with $\mathrm{p} 53$ inactivation, thus supporting the incapacity of $\mathrm{p} 16^{\mathrm{INK} 4 \mathrm{a}}$ deficient cells to cope with acute telomere damage. Even periods of short acute telomere deprotection did not dramatically alter the cell cycle profile of $\mathrm{p} 16^{\mathrm{INK} 4 \mathrm{a}}$ deficient cells or give rise to an intensification of the telomere-dependent CIN over time. Collectively, this indicates that cells experiencing transient acute telomere damage cannot overcome the severe proliferation defect imposed by uncapped telomeres and are destined to die.

\section{RESULTS}

The MCF-10A cell line is a spontaneously immortalised, but non-transformed human mammary epithelial cell line derived from breast tissue [28]. This cell line maintains telomere length through telomerase, but its expression is low [29, 30], making it hard to see a clear band of hTERT by western blotting (Supplementary Figure 1). Furthermore, despite being commonly recognised as normal cells, the karyotype is cytogenetically abnormal (Supplementary Figure 2A) and harbours genetic abnormalities commonly associated with cultured mammary epithelial cells such as deletion of the locus containing $\mathrm{p} 16^{\mathrm{INK} 4 \mathrm{a}}$ and $\mathrm{p} 14^{\mathrm{ARF}}$, as well as MYC amplification [31, 32].

\section{Establishment of conditional TRF2 ${ }^{\mathrm{AB} \Delta \mathrm{M}} \mathrm{MCF}$ - 10A cell lines with different cell cycle settings}

Different MCF-10A cell lines were generated to display telomere dysfunction in a regulated manner through doxycycline (DOX)-induced expression of $\mathrm{TRF}^{\triangle \mathrm{B} \Delta \mathrm{M}}$ (Figure 1A). The MCF-10A T/O TRF2 ${ }^{\triangle \mathrm{B} \Delta \mathrm{M}}$ (TO) cell line was generated after serially transducing MCF10A cells with lentiviral particles containing the inducible $\mathrm{TRF} 2^{\triangle \mathrm{B} \Delta \mathrm{M}}$ cassette and the rtTA3 transactivator (Figure $1 \mathrm{~B})$. Because abrogation of the $\mathrm{p} 53$ and $\mathrm{pRb}$ pathways is needed in human cells to bypass senescence and to initiate rampant telomere-dependent $\mathrm{CIN}$, we established a second MCF-10A T/O TRF2 ${ }^{\triangle \mathrm{B} \Delta \mathrm{M}}$ inducible cell line where p53 expression was constitutively abolished using shorthairpin p53 RNA lentiviral particles (SH-TO) (Figure 1B). After antibiotic selection, diminished levels of p53 were verified through western blotting (Figure $1 \mathrm{C}$ and Supplementary Figure 3A). Besides that, inactivation of the p53 pathway was confirmed by the fact that increased levels of $\mathrm{p} 53^{\mathrm{S} 15}$ and $\mathrm{p} 21^{\mathrm{Waf} 1 / \mathrm{Cip} 1}$ were practically unnoticed after cell exposure to the DSBs inducer Bleocin ${ }^{\mathrm{TM}}$ (Figure $1 \mathrm{C}$ and Supplementary Figure $3 \mathrm{~A}$ ) and by the increased ability of tetraploid cells to re-enter the cell cycle and initiate another round of DNA replication after $24 \mathrm{~h}$ colcemid exposure and release (Supplementary Figure 4). Moreover, as an independent way of inactivating the $\mathrm{pRb}$ and $\mathrm{p} 53$ pathways, we generated a third TRF2 ${ }^{\triangle \mathrm{B} \Delta \mathrm{M}}$ conditional MCF-10A model (SV-TO) by transducing TO cells with a lentivirus that constitutively expresses the Large $\mathrm{T}$ antigen gene from SV40 and mCherry 
A

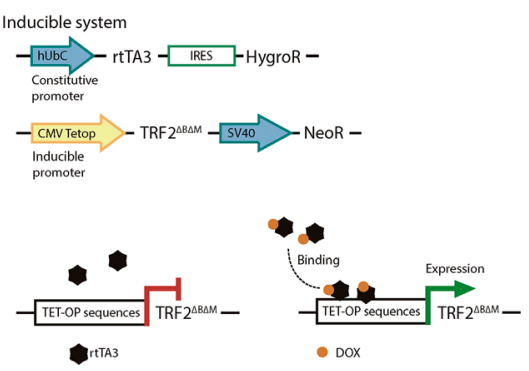

B

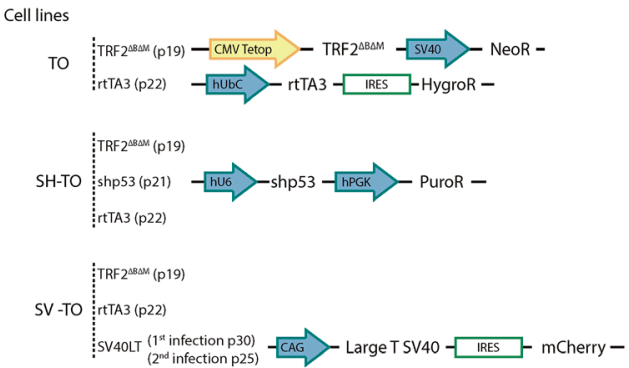

C
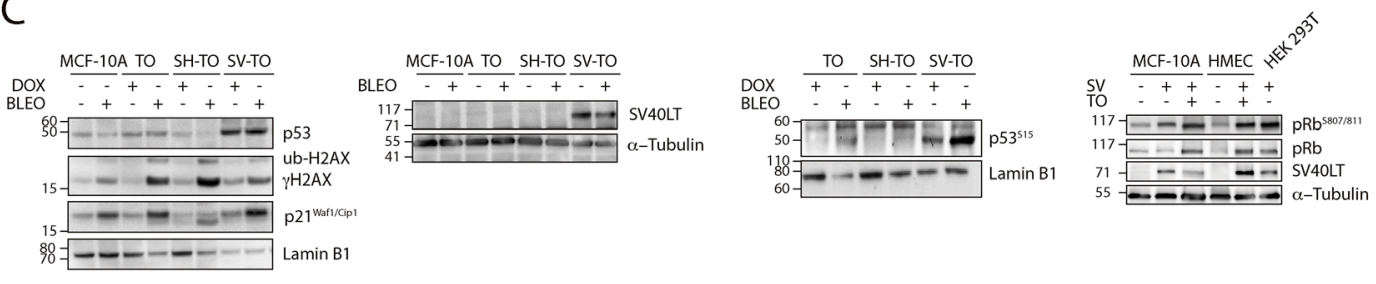

D

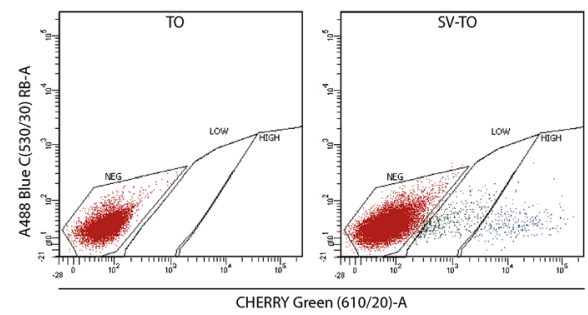

$\mathrm{E}$

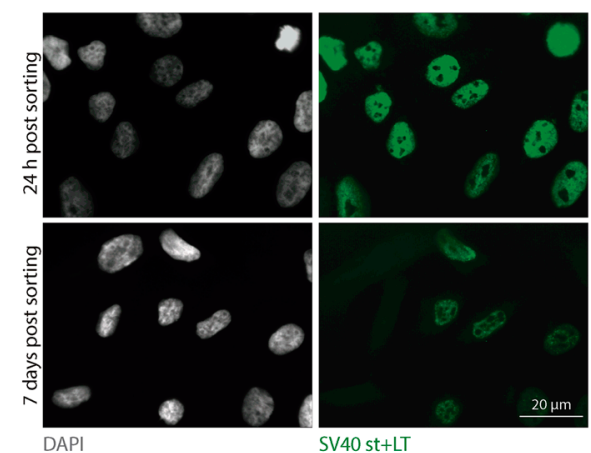

Figure 1: Generation of different MCF-10A cell lines with inducible TRF2 ${ }^{\Delta \mathrm{B} \Delta \mathrm{M}}$ expression. (A) Scheme of the conditional TET-ON expression system for TRF $2^{\triangle \mathrm{B} \Delta \mathrm{M}}$. The doxycycline-inducible system consisted in the constitutive expression of the rtTA3 protein through the hUbC (Ubiquitin C) promoter and the TRF2 ${ }^{\triangle \mathrm{B} \Delta \mathrm{M}}$ protein under the inducible CMV (Citomegalovirus)-Tetop promoter. In the absence of the tetracycline-derivative doxycycline (DOX), the rtTA3 protein is unable to bind to the TET-OP sequences located at the promoter; consequently, gene expression is repressed. In contrast, when DOX is added to the cell culture, it binds to rtTA3, which subsequently undergoes a conformational change that allows it to bind to the inducible promoter, starting TRF2 ${ }^{\Delta \mathrm{B} \Delta \mathrm{M}}$ transcription. (B) All cell lines (TO; SH-TO and SV-TO) contained the doxycycline-expression system. In addition to these modifications, SH-TO cell lines were transduced with the short hairpin RNA of p53 under the hU6 constitutive promoter. And the SV-TO cell line expressed the SV40 Large $\mathrm{T}$ antigen and mCherry under the CAG (CMV enhancer-chicken beta actin) constitutive promoter. All constructs contained a selectable marker or a resistence gene for selection purposes, under the same or a different promoter. The inducible MCF-10A cell lines (TO; SH-TO; SV-TO) were generated through serial transduction with TRF2 ${ }^{\triangle \mathrm{B} \triangle \mathrm{M}}$ (passage 19), rtTA3 (passage 22), shp53 (passage 21) or SVLT40mCherry (passage 25 and 30) lentivirus. (C) Immunoblots of untreated and DOX- or Bleocin ${ }^{\mathrm{TM}_{-}}$-treated MCF-10A and TO, SH-TO and SV-TO cell lines. Diminished levels of p53 were observed in the SH-TO cell line as well as reduced levels of p53 $3^{\mathrm{S} 15}$ and $\mathrm{p} 21^{\mathrm{Wafl} / \mathrm{Cip} 1}$ after DSBs induction by Bleocin ${ }^{\mathrm{TM}}$, thus validating short hairpin RNA p53 inactivation. In SV-TO cells, western blots confirmed the presence of SV40 Large T antigen. In this cell line, higher $\mathrm{p} 53$ and $\mathrm{p} 53^{\mathrm{S} 15}$ levels are observed due to $\mathrm{p} 53$ stabilisation by LT antigen. After DSBs induction by Bleocin ${ }^{\mathrm{TM}}$ exposure, both TO and SV-TO cells showed enhanced $\mathrm{p} 53^{\mathrm{S} 15}$ and $\mathrm{p} 21^{\text {Wafl/Cip1 }}$ levels. The loss of the G1 growth suppressor function of $\mathrm{pRb}$ was determined by the ratio between $\mathrm{pRb} \mathrm{b}^{\mathrm{S} 807-811} /$ total $\mathrm{pRb}$. Cell lines containing the SV40LT antigen showed higher $\mathrm{pRb}^{\mathrm{S} 807 / 811}$ levels than uninfected cell lines, thus supporting inactivation of pRb protein. (D) SV-TO cells were selected by FACS of cells expressing mCherry. SV40LT-mCherry uninfected TO cells were used as control to discard cell autofluorescence. The FACS profile of SV-TO MCF-10A cell line shows weakly and strongly mCherry expressing populations. For the following experiments, SV-TO cells with strong mCherry expression were used. (E) SV40 T-antigens (st+LT) immunofluorescence in SV-TO cells $24 \mathrm{~h}$ and one week after FACS sorting. Immunofluorescent images, captured under the same exposure conditions, denote the partial loss of T-antigen expression over time. Scale bar corresponds to $20 \mu \mathrm{m}$. 
(Figure 1B). The translation product of SV40LT functions as a viral oncoprotein, which upon binding to p53 and $\mathrm{pRb}$ proteins inhibits their functions [33]. Selection of SV40LT containing cells was done by fluorescence activated cell sorting (FACS) of mCherry positive cells (Figure 1D) and afterwards SV40LT expression was validated by western blot, immunofluorescence and flow cytometry. As expected, the Large $\mathrm{T}$ antigen was present in SV-TO whole cell extracts and detected in the nucleus of transduced cells by immunofluorescence (Figure 1C and 1E). However, we found that SV40LT expressing cells were gradually lost from the culture (Figure 1E). Additional experiments with the $\mathrm{p} 16^{\mathrm{INK} 4 \mathrm{a}}$-deficient $\mathrm{MCF}$ 10A cells demonstrated again the loss of SV40LT positive cells with time (Supplementary Figure 5A and 5B). This leaking effect was previously reported to occur in $\mathrm{p} 16^{\text {INK4a }}$ deficient human mammary epithelial cells (vHMECs) transduced with SV40 early region (st and LT antigens) $[34,35]$. To validate this, HMECs derived from cosmetic breast reductions were transduced with the same SV40LT antigen-mCherry vector. In this case, HMECs-hTERT were infected at an early population doubling (PD 6.92) before $\mathrm{p} 16^{\mathrm{INK} 4 \mathrm{a}}$ inactivation takes place and we did not pick clones or select for mCherry cells by FACS. In those HMECs-hTERT-SV40LT, the leaking effect was not observed. But most importantly, the analysis of SV40LT antigen levels by western blotting and flow cytometry at $\mathrm{PD}>92.31$, demonstrated that cells were still positive for the Large $\mathrm{T}$ antigen (Supplementary Figure 5B and 5C). As a whole, and confirming previous studies, breast epithelial cells $\mathrm{p} 16^{\mathrm{INK} 4 \mathrm{a}}$-deficient are refractory to SV40 transformation. The reason why this occurs is unknown and further experiments would be needed to ascertain it.

Even though the generation of a stable SV-TO cell line over time was unsuccessful, at the time of the analysis, immunoblots revealed the presence of the SV40LT antigen (Figure 1C). The infection of cells with Large $\mathrm{T}$ antigen presumably renders the cells oblivious to the DNA damage checkpoint by inactivating both $\mathrm{pRb}$ and $\mathrm{p} 53$. SV40LT antigen triggers $\mathrm{p} 53^{\mathrm{S} 15}$ and stabilises $\mathrm{p} 53$ protein, but it is suggested that the direct interaction between SV40LT and p53 inhibits its function as a transcription factor [36]. In SVTO cells, immunoblots demonstrated stabilisation of p53 by a higher expression of both $\mathrm{p} 53^{\mathrm{s} 15}$ and $\mathrm{p} 53$ in comparison with the other cell lines (Figure 1C and Supplementary Figure 3A). However, after Bleocin ${ }^{\mathrm{TM}}$ treatment the cells were capable of upregulating $\mathrm{p} 53^{\mathrm{S} 15}$ and $\mathrm{p} 21^{\text {Wafl/Cipl }}$ (Figure $1 \mathrm{C}$ and Supplementary Figure 3A). Given that it was not clear whether upregulation was due to the improper p53 pathway inactivation or to the presence of SV-TO cells lacking the SV40LT antigen, the response of SV-TO cells to acute colcemid treatment was also evaluated. Coincident with SH-TO cells, a significant polyploid population was observed in SV-TO cells $48 \mathrm{~h}$ after colcemid treatment (Supplementary Figure 4) thus supporting that at least the p53 pathway was abrogated in some cells. To determine the functional inactivation of the $\mathrm{pRb}$ pathway we tested the expression of the retinoblastoma pocket protein $\mathrm{pRb}$ (p105) and its phosphorylated form $\mathrm{pRb}^{\mathrm{S} 807 / 811}$ (Figure $1 \mathrm{C})$, as Large $\mathrm{T}$ antigen binds and inactivates $\mathrm{pRb}$ pocket

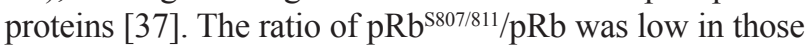
cells not containing the SV40LT antigen (Supplementary Figure $3 \mathrm{~B}$ ). In cells expressing the LT antigen, $\mathrm{pRb}$ was in a more hyper-phosphorylated state and higher $\mathrm{pRb}^{\mathrm{s807/811/}}$ $\mathrm{pRb}$ ratios were detected, thus suggesting alleviation of the pRB-mediated repression checkpoint.

Finally, the specific genetic changes present in the parental MCF-10A cell line were evaluated (Supplementary Figure 2A). The modal karyotype at p15 was defined as 47, XX, i(1q), del(1q), +1, der(3)t(3;9), der(8)t(8;8), $\operatorname{der}(9) \mathrm{t}(9 ; 3 ; 5)$. In addition to these clonal aberrations, previously described in the literature [38-40], some signs of CIN were found. A total of $10.81 \%$ of non-modified MCF-10A metaphases showed non-clonal chromosome aberrations including chromosome fragments, chromatid breaks and one dicentric chromosome that showed telomeric FISH signals at the fusion point (Supplementary Table 1). Karyotyping by reverse DAPI banding was also performed in the uninduced TO, SH-TO and SV-TO cell lines to determine the cytogenetic impact of the genetic modifications (Supplementary Figure 2 and Supplementary Table 1). Collectively, these data suggested that the establishment of the TET-ON inducible system did not have a deleterious effect on the karyotype of MCF-10A epithelial cells. By contrast, and as previously reported [41], diminished levels of p53 resulted in an increase of cells containing chromosome aberrations with regard to the parental MCF-10A (Supplementary Figure 2). This adverse effect was markedly opposed if disruption was achieved through short hairpin RNA interference or SV40LT infection. Whereas shp53 resulted in an increase in nonclonal unstable aberrations that included rejoined broken chromosomes, acentric fragments and chromosome breaks, SV40LT transduction resulted in clonal stable chromosome aberrations (Supplementary Figure 2). This divergent result could be explained by the time elapsed between infection and the cytogenetic analysis. Due to the loss of SV40LT expression, SV-TO cells were analysed shortly after transduction and sorting, while much time passed between infection, selection and chromosome analysis in the SH-TO cell line. Given that the chromosome damage induced by SV40LT is an active process that gradually increases with serial cell passage [42] (Supplementary Figure 5D), the prompt analysis of the SV-TO cell line after transduction avoided the adverse evolution of the karyotype.

\section{Variable intensity of telomere dysfunction upon $96 \mathrm{~h}$ sustained $\mathrm{TRF}^{\mathrm{AB \Delta M}}{ }^{\mathrm{B}}$ expression in the modified MCF-10A cell lines}

To validate the efficacy of the inducible system, we exposed the parental MCF-10A and the three modified 
cell lines to doxycycline for $96 \mathrm{~h}$. The expression of the truncated $\mathrm{TRF} 2^{\triangle \mathrm{B} \Delta \mathrm{M}}$ protein upon DOX addition was demonstrated by immunoblotting protein extracts from untreated and DOX-treated cells with full length TRF2 antibodies (Figure 2A and Supplementary Figure 3C).

Then, the telomere dysfunction phenotype was evaluated through a deep cytogenetic analysis of metaphase spreads from $96 \mathrm{~h}$ DOX-treated and uninduced matched cells. Overall, the frequency of aberrant metaphases significantly increased in the TO cell line expressing TRF2 ${ }^{\triangle \mathrm{B} \Delta \mathrm{M}}(8.57 \%$ vs. $45.45 \%$; $\mathrm{p}=$ $0.0002)$, but strikingly this was not the case for $\mathrm{SH}-\mathrm{TO}$ (55.56\% vs. $67.39 \%$; $\mathrm{p}=0.3594)$ nor for SV-TO $(71.05 \%$ vs. $82.86 \%$; $\mathrm{p}=0.2767$ ) (Figure $2 \mathrm{~B}$ and Supplementary Table 1). This observation was probably due to the high frequency of abnormal karyotypes induced by p53 or $\mathrm{p} 53 / \mathrm{pRb}$ inactivation. Indeed, clear evidence of the telomere dysfunction phenotype was observed when only metaphase spreads showing chromosome fusions were considered (Figure 2C). TRF $2^{\triangle \mathrm{B} \Delta \mathrm{M}}$ expression for 4 days induced a significant increase in metaphase cells showing end-to-end fusions (TO $\mathrm{p}=0.0002$; $\mathrm{SH}-\mathrm{TO} \mathrm{p}=0.0072$ and SV-TO $p<0.0001$ ) (Supplementary Table 1). On average, there were 0.65 fusion events per cell in TO, 1.67 in $\mathrm{SH}-$ TO and 2.14 in SV-TO after expression of the dominant negative form of TRF2, which is statistically higher than the rates observed in matched uninduced cell lines (MannWhitney U-test; TO $\mathrm{p}=0.0003$; SH-TO $\mathrm{p}=0.0035$ and SVTO $\mathrm{p}<0.0001$ ) (Figure 2D and Supplementary Table 1). Chromosome-type fusions, i.e. dicentric chromosomes formed during G1 were more frequently observed than chromatid-type fusions, which typically originate in the G2 phase of the cell cycle (Supplementary Figure 6). Usually both types of fusions involved two chromosomes, though multiple concatenated chromosomes were occasionally observed in the SH-TO and SV-TO cell lines (Figure 2E). At that point, in order to unambiguously demonstrate that telomere fusions were due to chromosome ends lacking sufficient TRF2 protection, we performed PNA-FISH experiments with pancentromeric and pantelomeric PNA-probes. In uninduced cells, most fusion events did not display TTAGGG FISH signals at the junction point, probably indicating DSB-DSB rejoining as origin. By contrast, after $\mathrm{TRF} 2^{\triangle \mathrm{B} \Delta \mathrm{M}}$ expression, the vast majority of fusion events displayed telomeric FISH signals at the fusion point $(94.29 \%$ telomere positive fusions in $\mathrm{TO}$, $84.72 \%$ in SH-TO and $91.55 \%$ in SV-TO) (Figure $3 \mathrm{~A}$ and $3 \mathrm{~B}$, and Supplementary Table 2), thus demonstrating the presence of telomeric DNA and validating the efficacy of our telomere dysfunction inducible system.

Additionally, the telomere dysfunction phenotype was assessed by analysing the presence of anaphase bridges. A minimum of 215 anaphases were examined in uninduced and doxycycline-treated modified cell lines (Supplementary Table 3). The presence of cells with chromatin bridges during anaphase was low in TO and SV-TO cells not expressing the truncated TRF2 protein $(3.72 \%$ and $4.21 \%$, respectively). By contrast, the percentage of cells displaying anaphase bridges in uninduced SH-TO increased to $18.93 \%$, which is statistically higher than the others $(\mathrm{p}<$ 0.0001 ) (Figure 3C and 3D, and Supplementary Table $3)$. This agrees with the high frequency of chromosome fusion events displayed by SH-TO cells when TRF2 ${ }^{\Delta \mathrm{B} \Delta \mathrm{M}}$ was not induced (Supplementary Table 1). After $96 \mathrm{~h}$ of acute telomere dysfunction, there was a significant increase in cells containing anaphase bridges in all the cell lines expressing $\mathrm{TRF} 2^{\mathrm{B} \Delta \mathrm{M}}$ when compared with matched uninduced cell lines $(\mathrm{p}<0.0001)$ (Figure 3C and 3D, and Supplementary Table 3 ).

Overall, the expression of TRF $2^{\triangle \mathrm{B} \Delta \mathrm{M}}$ during $96 \mathrm{~h}$ leads to a telomere-dysfunction phenotype whose level of intensity depends on the functionality of cell cycle checkpoints. TO cells, which are $\mathrm{p} 16^{\mathrm{INK} 4 \mathrm{a}}$-deficient but present wild-type p53, showed the lowest percentage of cells with end-to-end fusions, as well as the smallest frequency of fusions per cell. In sharp contrast, the telomere-dysfunction phenotype was exacerbated in the SV40 LT antigen transduced cells, thus confirming that disabled cell-cycle checkpoints allow the accumulation and survival of cells containing telomere damage.

\section{Acute telomere deprotection fires BFB cycles but prevents the development of CIN}

Cells undergoing telomere dysfunction set in motion BFB cycles that, following chromatin bridge resolution, give rise to chromosome structural aberrations, gains and losses of chromosomes (aneuploidy) and regional amplification (reviewed by [7, 43]). Most recently, chromothripsis and kataegis have also been documented to occur after chromatin bridge fragmentation [44]. Besides that, several studies in human cells and in the mouse have clearly shown that deprotection of chromosome ends leads to polyploidisation events $[45,46]$.

To evaluate the presence of telomere-dependent CIN we analysed for BFB cycles scars in the form of structural chromosome aberrations other than end-to-end fusions. Structural reorganisations such as non-clonal non-reciprocal translocations (NRT) were few and did not increase after TRF $2^{\triangle \mathrm{B} \Delta \mathrm{M}}$ expression. This result was quite unexpected, given the significant increase of cells with chromatin bridges after telomere damage.

Besides that, FISH analysis with three different centromeric specific probes was also conducted to ascertain whether TRF2 $2^{\triangle \mathrm{B} \Delta \mathrm{M}}$ expression engendered numerical chromosome changes. Chromosomes \#6, $\# 12$ and \#17 were selected for their uninvolvement in numerical aberrations in the parental MCF-10A and uninduced cell lines (Supplementary Figure 2). The specificity of the centromeric probes was determined on metaphase chromosomes (Figure 4A) and aneuploid configurations were evaluated in a minimum of 
A

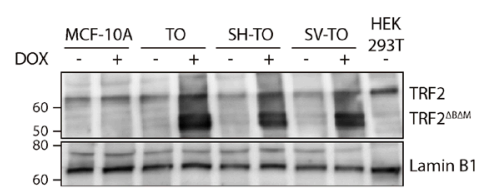

B

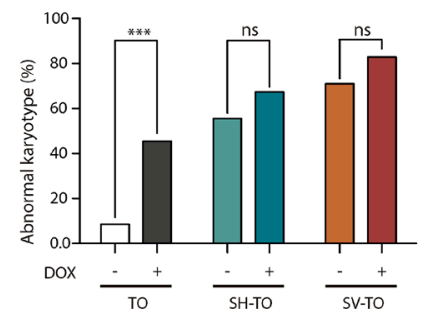

C

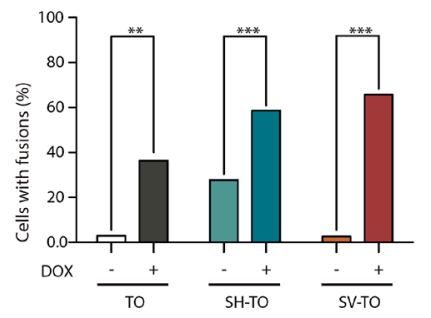

D

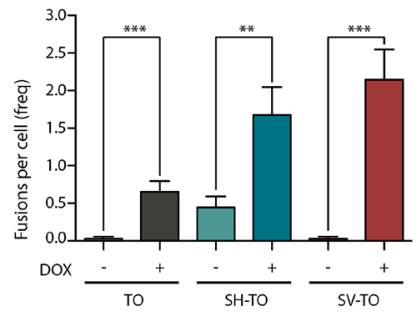

E

TO DOX

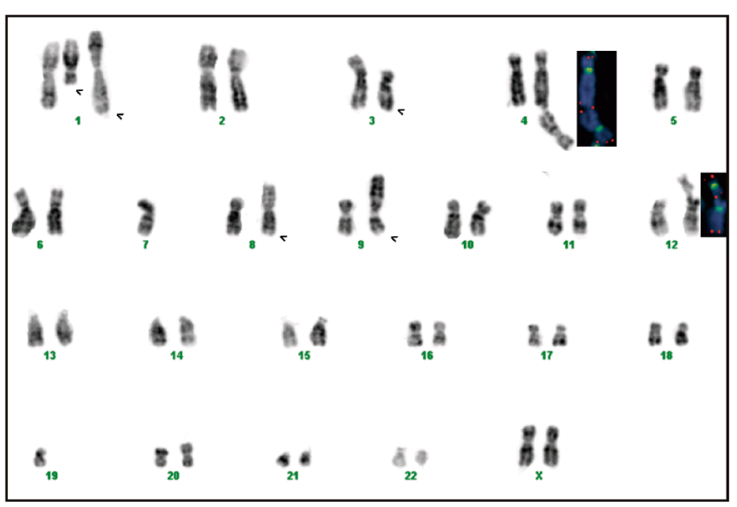

SV-TO DOX

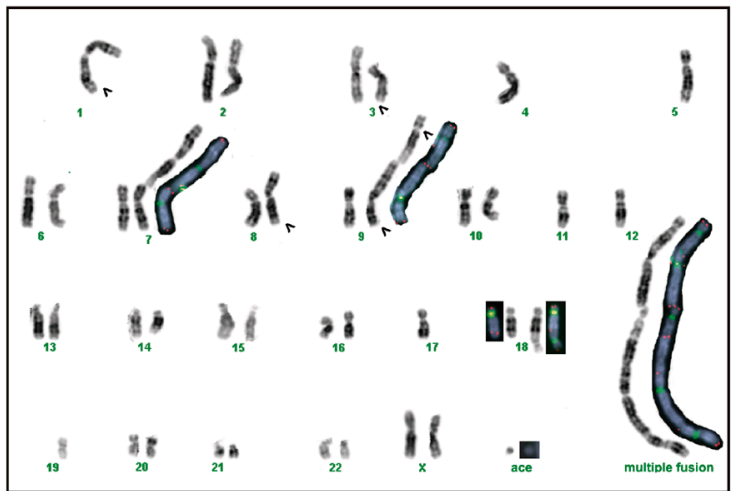

SH-TO DOX

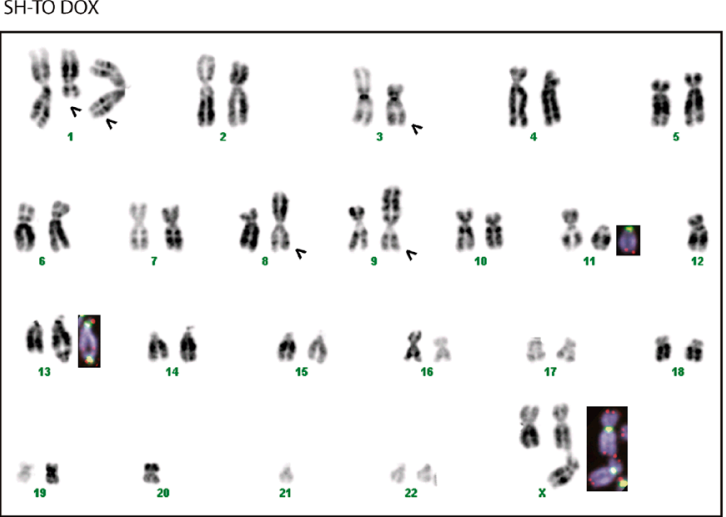

\section{.}


284 interphase nuclei of treated and untreated cells (Supplementary Table 4). The percentage of $2 \mathrm{~N}$ aneuploid cells ranged from $4.66 \%$ to $14.10 \%$ and, upon doxycycline addition, this fraction did not increase in any of the modified cell lines $(p=0.0743, p=0.9162$ and $p=0.2567$, for TO and SH-TO and SV-TO, respectively) (Figure 4B and $4 \mathrm{C}$ ). Tetraploid events in uninduced TO cells were few (Figure 4C and 4D), but according to the role of p53 in limiting the proliferation of polyploids, the fraction of tetraploid cells in untreated SH-TO and SV-TO cells was significantly higher than in TO $(p<0.0001$ and $p=0.0094$, respectively). Nevertheless, tetraploidisation events in SV-TO cells were significantly fewer than those in SHTO cells, which was unexpected considering that SV40LT also inhibits p53 function. Strikingly, upon TRF2 ${ }^{\triangle B} \Delta \mathrm{M}$ expression the fraction of tetraploid cells was exacerbated only in SH-TO cells $(p=0.0099)$. This result was quite surprising as given the elevated level of end-to-end fusions in SV-TO metaphases, we rather expected similar results for the SV-TO cell line. However, such was not the case, and indeed we found that the fraction of $4 \mathrm{~N}$ cells in induced SV-TO was similar to that observed in treated TO cells $(p=0.3349)$. Moreover, the fraction of tetraploid cells displaying aneuploid configurations increased upon $\mathrm{TRF}^{\triangle \mathrm{B} \Delta \mathrm{M}}$ expression when $\mathrm{p} 53$ was attenuated $(2.78 \%$ vs. $7.04 \%$ in SH-TO and $0.86 \%$ vs. $1.91 \%$ in SV-TO), however statistical significance was only denoted for $\mathrm{SH}$ TO cells $(\mathrm{p}=0.0059)$ (Figure 4C).

As a whole, chromosome banding of metaphase spreads and centromeric-specific FISH analysis in interphase nuclei demonstrated the failure of long-term telomere deprotection to induce extensive structural and
A

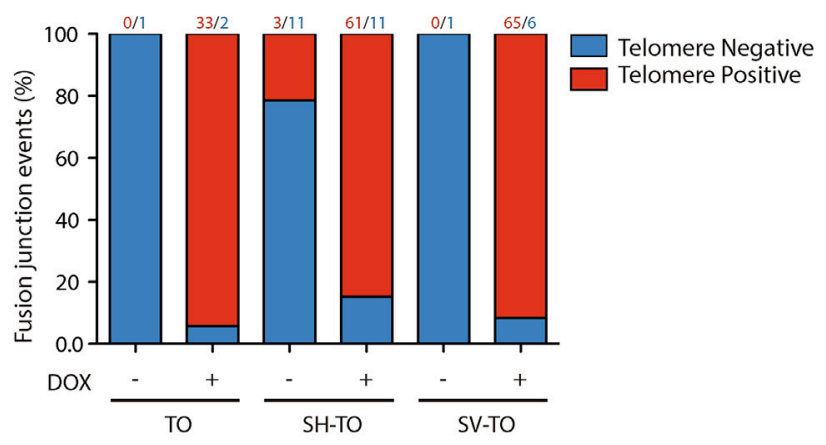

C

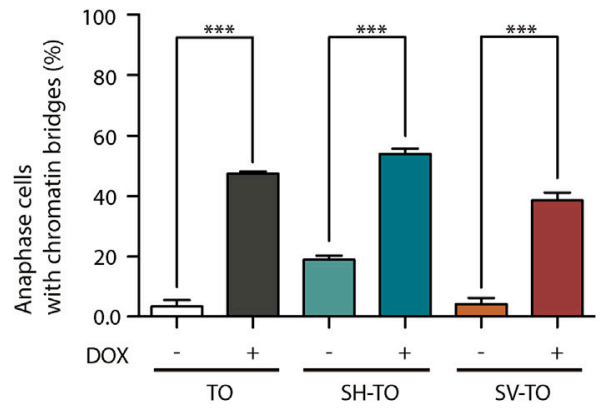

B

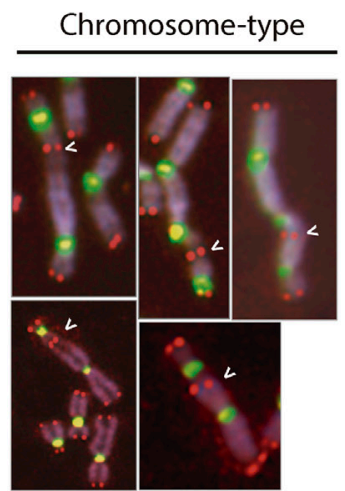

DAPI Telomere Centromere

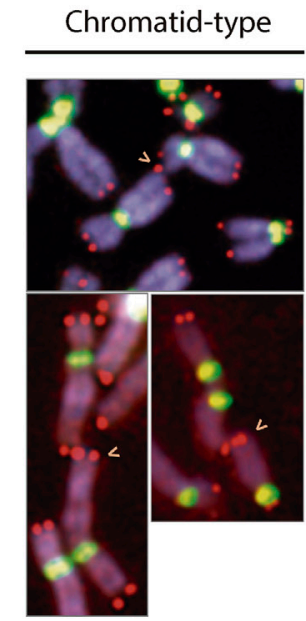

D

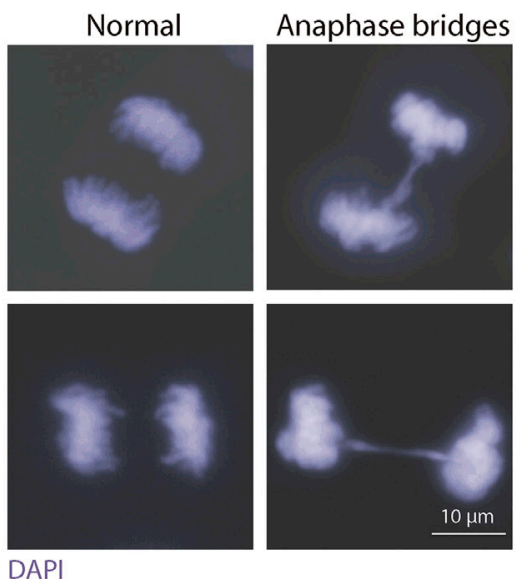

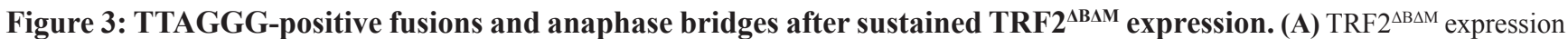
significantly increased the percentage of fusion events displaying TTAGGG repeats at the fusion point, thus confirming that fusions occurred because of the unfolded t-loop structure and not telomere DNA shortening. The number of events of each category is shown above the bars. (B) TRF2 stripped telomeres mostly fused at the G1 cell cycle phase, giving rise to chromosome-type fusions. Chromatid-type fusions that formed in G2 were also observed, although to a lower extent. (C) The expression of TRF2 $2^{\triangle \mathrm{B} \Delta \mathrm{M}}$ also increased the proportion of anaphase cells with chromatin bridges, another marker of telomere dysfunction. Data are presented as mean + SEM from three independent experiments. (D) Representative images of anaphase cells without (left) and with (right) chromatin bridges. Scale bar corresponds to $10 \mu \mathrm{m}$. 
numerical changes compatible with ongoing BFB cycles. Therefore, these data suggest that sustained $96 \mathrm{~h}$ of acute telomere deprotection prevents active proliferation of cells suffering telomere damage.

\section{Transient cycles of $96 \mathrm{~h}$ acute telomere damage results in proliferation defects in the absence of cell cycle alterations, DDR activation and visible senescent and apoptotic markers}

Whereas persistent disruption of TRF2 activates a DDR that signals cell cycle arrest or apoptosis [23, 24], the fate of cells experiencing transient periods of acute telomere deprotection remains unclear. To this end, cell cycle progression studies were conducted in the modified MCF-10A cell lines after switching on/off TRF2 ${ }^{\triangle \mathrm{B} \Delta \mathrm{M}}$ expression. First, we analysed DOX-mediated cell cycle profile changes in unmodified MCF-10A cells to assess potential detrimental effects of DOX on cell proliferation [47]. After $24 \mathrm{~h}$ or $96 \mathrm{~h}$ exposure, we did not find evidence that $1 \mu \mathrm{g} / \mathrm{ml}$ DOX affected the cell cycle profile of unmodified MCF-10A cells (Mann-Whitney U-test; p> 0.05) (Supplementary Figure 7).

Then, asynchronous untreated cultures, subjected to doxycycline for $96 \mathrm{~h}$, as well as those recovered after one or two cycles of $96 \mathrm{~h}$ DOX exposure and washout, were monitored by FACS analyses of DNA content. No significant alterations were observed in the cell cycle
A

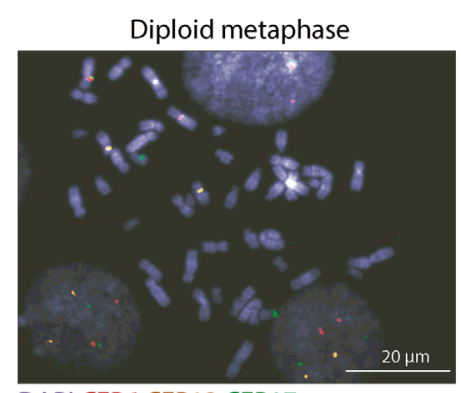

DAPI CEP6 CEP12 CEP17
B

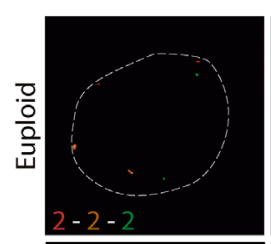

$2 \mathrm{~N}$
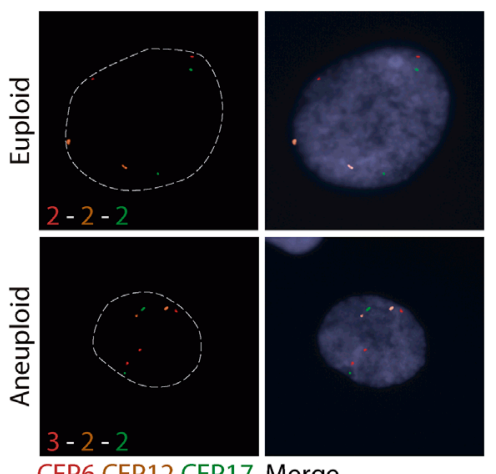

CEP6 CEP12 CEP17 Merge
$4 N$

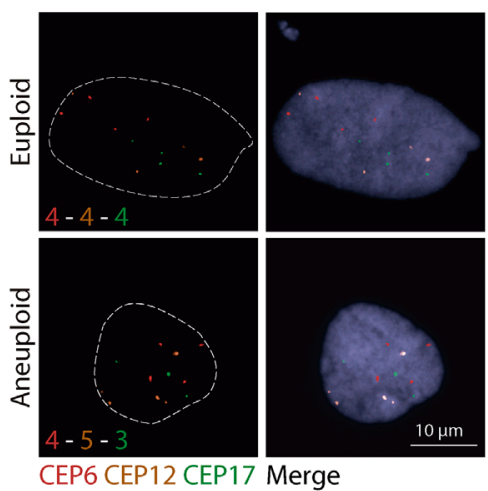

C

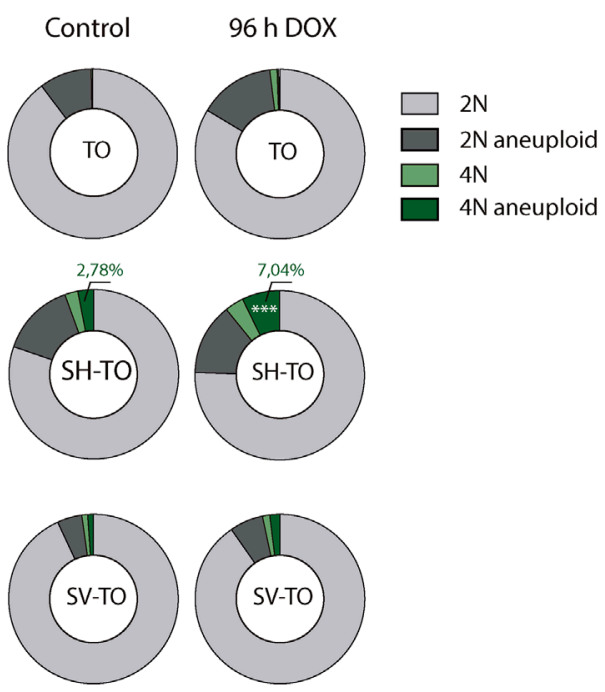

D

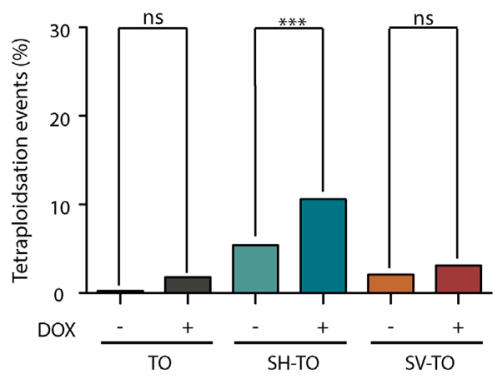

Figure 4: Tetraploidisation is not the usual fate of cells experiencing sustained TRF2 ${ }^{\Delta \mathrm{B} \Delta \mathrm{M}}$ expression. (A) Representative image of a diploid metaphase, showing the specificity of the centromeric probes tested: chromosomes 6 (red), 12 (yellow) and 17 (green). Scale bar corresponds to $20 \mu \mathrm{m}$. (B) Representative images of diploid and tetraploid cells with euploid and aneuploid configurations of tested centromeric probes. Scale bar corresponds to $10 \mu \mathrm{m}$. (C) Aneuploid configurations after TRF2 depletion only increased in the 4N fraction of SH-TO cells. (D) Percentage of tetraploid cells before and after TRF2 ${ }^{\Delta \mathrm{B} \Delta \mathrm{M}}$ expression. Tetraploid cells significantly increased in the SH-TO cell line after DOX treatment. In contrast, this was not the case for TO or SV-TO cell lines $(\mathrm{p}=0.0375$ and $\mathrm{p}=0.3122$, respectively; Bonferroni p-value correction $=0.0167$ ). 
A $1^{\text {st }}$ cycle
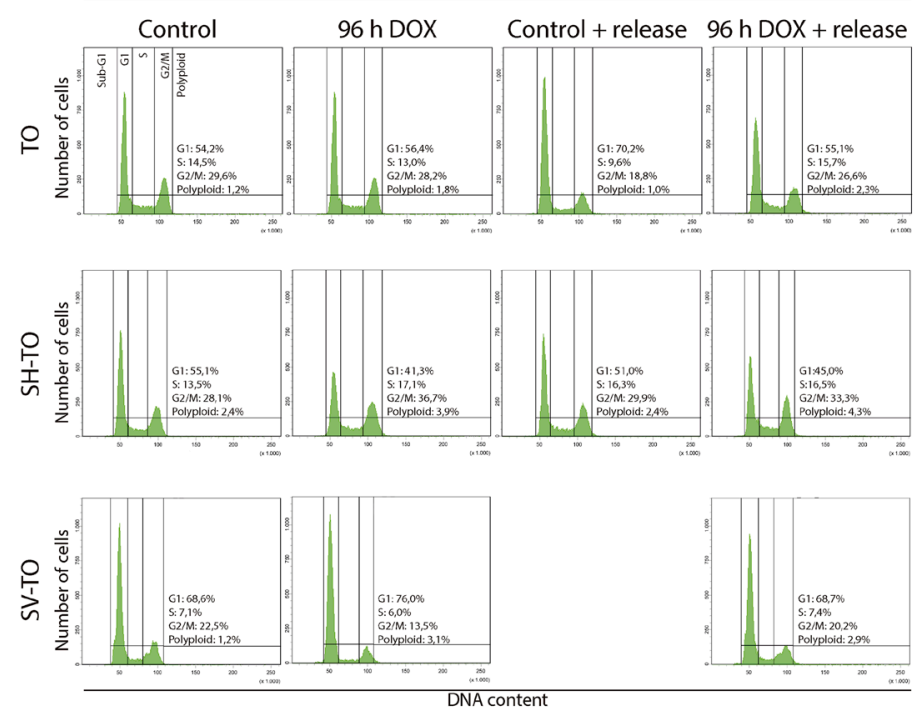

B
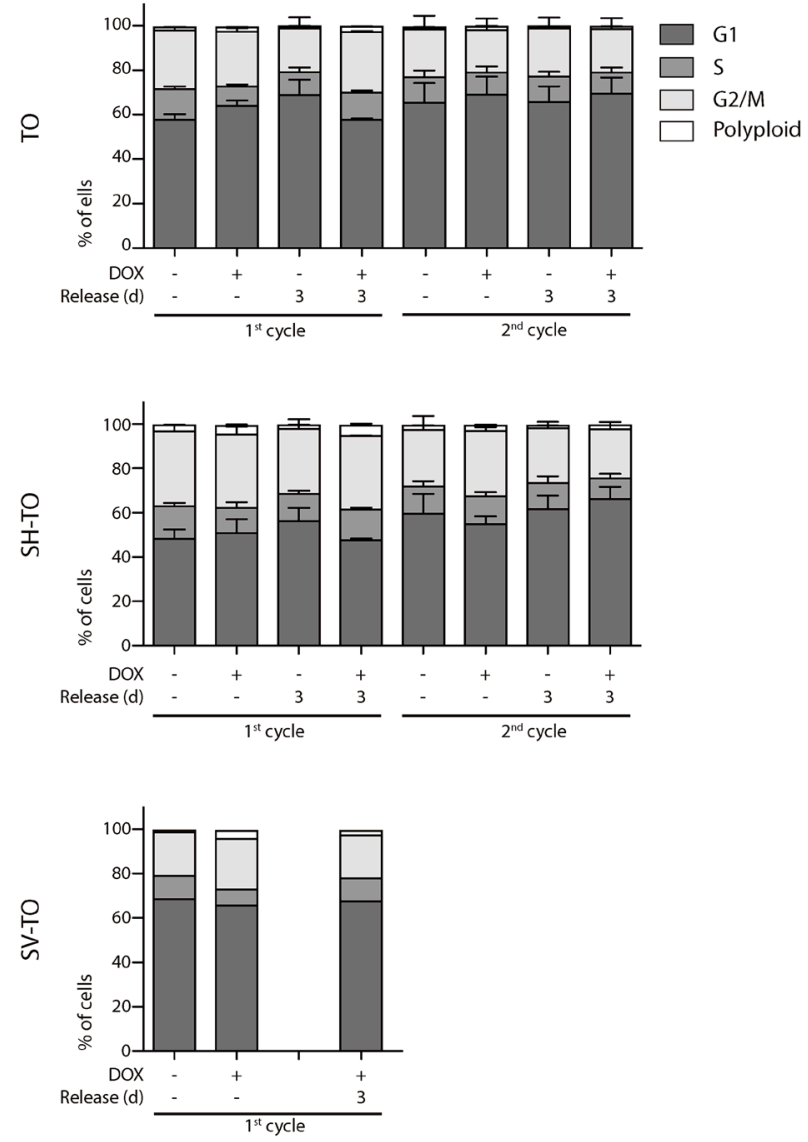

Figure 5: Absence of cell cycle profile disturbances after long TRF2 ${ }^{\triangle \mathrm{B} \Delta \mathrm{M}}$ expression periods. (A) Representative cell cycle profiles of TO, SH-TO and SV-TO cell lines during the first cycle of $96 \mathrm{~h}$ DOX treatment and their respective controls. Cell cycle profiles remained stable throughout the time of the experiment. Cell cycle phases are marked and values indicated. (B) Cell cycle phases distribution among TO, SH-TO cell lines (first and second cycle) and SV-TO cell line (first cycle) after $96 \mathrm{~h} \mathrm{DOX} \mathrm{experiments.} \mathrm{No} \mathrm{statistical} \mathrm{differences}$ were observed between control and treated samples (Mann-Whitney test). A minimum of 10,000 cells were analysed per experiment. Data are presented as mean + SEM from three independent experiments, except for SV-TO cell line, in which only one experiment is shown. 
profile of the modified cell lines after $96 \mathrm{~h}$ of sustained $\mathrm{TRF}^{\triangle \mathrm{B} \Delta \mathrm{M}}$ expression or after three days release (first DOX cycle) (Mann-Whitney U-test; $\mathrm{p}>0.05$ ) (Figure 5A and $5 \mathrm{~B}$ ). Moreover, exposure of TO and SH-TO cells to a second cycle of TRF $2^{\triangle \mathrm{B} \Delta \mathrm{M}}$ expression did not perturb the cell cycle profile either (Mann-Whitney U-test; $\mathrm{p}>0.05$ ). These observations agreed with the absence of changes in the S-phase index after $96 \mathrm{~h}$ telomere damage analysed through incorporation of BrdU (data not shown, only one experiment). Although the cell cycle arrest was not detected, TRF $2^{\triangle \mathrm{B} \Delta \mathrm{M}}$ sustained expression during four days resulted in a significant reduction of cell proliferation in both TO and SH-TO cells (Mann-Whitney U-test; TO p= 0.0087; SH-TO $p=0.0032$ ) (Figure 6A). Despite the fact that end-to-end telomere fusions can slow progression through mitosis thus misleading cell proliferation changes, the absence of genomic instability compatible with ongoing BFB cycles also supports the notion that cells stop proliferation and ultimately senesce or die. However, no obvious senescent morphology was observed in the modified MCF-10A cells undergoing TRF2 depletion (Figure 6A). Furthermore, TRF2 ${ }^{\triangle \mathrm{B} \triangle \mathrm{M}}$ expressing cells were indistinguishable from control cultures by SA- $\beta$ galactosidase activity staining (Kruskal Wallis and Dunn's multiple comparison test; $\mathrm{p}>0.05$ ) (Figure 6B), which agrees with studies reporting abrogation of senescence in p16 $6^{\text {INK4a }}$-deficient cells [48]. These results together with the observation that apoptosis is triggered in p16 $6^{\mathrm{INK} 4 \mathrm{a}}$ deficient mammary adenocarcinoma MCF7 cell line upon $\mathrm{TRF}^{\triangle \mathrm{B} \Delta \mathrm{M}}$ expression [23], evoked that the reduced proliferation in the modified MCF-10A cells was most likely due to cell death resulting from telomere damage. Nonetheless, a marked appearance of a Sub-G1 fraction of cells by FACS analysis compatible with apoptosis was not observed after $96 \mathrm{~h} \mathrm{TRF} 2^{\mathrm{B} \Delta \mathrm{M}}$ expression (Figure 5A).

What is more, the response of several proteins involved in the DDR was considerably reduced in cells constitutively expressing $\mathrm{TRF} 2^{\triangle \mathrm{B} \Delta \mathrm{M}}$ during $96 \mathrm{~h}$ when compared to cells treated with the DSB-inducer Bleocin $^{\mathrm{TM}}$ (Figure 1C and Supplementary Figure 3A). Monoubiquitination of $\mathrm{H} 2 \mathrm{AX}$ ( $\mathrm{ub}-\mathrm{H} 2 \mathrm{AX}$ ), which functions as a proximal regulator in the DDR by initiating the DNA damage signalling through efficient $\gamma$-H2AX formation [49] was prominent in TO, SH-TO and SV-TO cells exposed to Bleocin ${ }^{\mathrm{TM}}$. By contrast, in DOX treated TO and SH-TO cells there was a reduced level of ub-H2AX. Only SV-TO cells showed a marked higher level of ub-H2AX, which could be related to the focal accumulation of $\gamma-\mathrm{H} 2 \mathrm{AX}$ associated with SV40LT antigen infection [50]. Furthermore, expression of p53, $\mathrm{p} 53^{\mathrm{S} 15}$ and $\mathrm{p} 21^{\mathrm{Waf} 1 / \mathrm{Cip} 1}$ followed the same trend, with a higher induction in Bleocin ${ }^{\mathrm{TM}}$ treated cells. In the face of telomere dysfunction induced by $\mathrm{TRF} 2^{\mathrm{AB} \Delta \mathrm{M}}$ expression, neither p53 nor p53 phosphorylation and p21 Waf1/Cipl upregulation could be detected in TO and SH-TO cells. As a whole, no evidence that $96 \mathrm{~h}$ of telomere dysfunction precipitates a DDR in the p16 $6^{\mathrm{INK} 4 \mathrm{a}}$-deficient $\mathrm{MCF}$ $10 \mathrm{~A}$ cells was found. This low level of DNA damage elicited after TRF2 depletion could be the reason for the ambiguous fate of cells carrying telomere damage.

\section{Even transient cycles of $24 \mathrm{~h}$ acute telomere dysfunction do not result in massive CIN}

Given that acute telomere dysfunction for $96 \mathrm{~h}$ impacted on the development of CIN and the growth rate of cells with telomere damage, we investigated whether shorter periods of telomere deprotection would allow the generation of endless BFB cycles and massive CIN.

Both $\mathrm{TO}$ and $\mathrm{SH}-\mathrm{TO}$ cells were exposed to successive $24 \mathrm{~h}$ periods of DOX treatment and washout. Cells retrieved after one or further $24 \mathrm{~h}$ DOX periods showed also an unaltered cell cycle profile (Mann-Whitney U-test; $p>0.05$ ) (Figure 7A and 7B). Moreover, cells that received five cycles of $24 \mathrm{~h}$ DOX and recovery retained the parental MCF-10A karyotype. Chromosome aberrations in the form of end-to-end fusions were observed, but no signs of ongoing BFB cycles were present in metaphase cells of TO or SH-TO after five $24 \mathrm{~h}$ DOX cycles. In addition, oligoFISH analysis revealed a significant reduction in aberrant cells after the fifth $24 \mathrm{~h}$ DOX cycle compared to uninduced matched cells $(p=0.0244$ and $p=0.0006$ for $\mathrm{TO}$ and $\mathrm{SH}-\mathrm{TO}$, respectively) (Figure $8 \mathrm{~A}$ ). In view of these results, expression of TRF $2^{\Delta \mathrm{B} \Delta \mathrm{M}}$ was evaluated in those cells subjected to the fifth doxycycline cycle to determine whether the unperturbed cell cycle profile and the decreased frequency of aneuploid configurations, at that time, were due to an increase outgrowth of cells with diminished TRF $2^{\Delta \mathrm{B} \Delta \mathrm{M}}$ expression. However, this was not the case, as western blot analysis demonstrated that cells retained $\mathrm{TRF} 2^{\triangle \mathrm{B} \Delta \mathrm{M}}$ expression during the fifth cycle of 24 $\mathrm{h}$ DOX in much the same way that cells express TRF2 ${ }^{\triangle \mathrm{B} \Delta \mathrm{M}}$ after $96 \mathrm{~h}$ of doxycycline (Figure 8B and Supplementary Figure $3 \mathrm{C}$ ). Then, we verified that $24 \mathrm{~h}$ of DOX exposure were sufficient to induce $\mathrm{TRF} 2^{\triangle \mathrm{B} \Delta \mathrm{M}}$ expression and that, after DOX washout, TRF2 $2^{\triangle \mathrm{B} \Delta \mathrm{M}}$ levels were reduced (Figure 8C and Supplementary Figure 3C). Finally, the efficacy of $24 \mathrm{~h}$ of DOX exposure in promoting uncapped telomeres was revealed by the presence of primary end-toend fusions and telomere dysfunction induced foci (TIFs) in mitotic cells (Figure 8D).

Together, these results somehow support the notion that $\mathrm{p} 16^{\mathrm{INK} 4 \mathrm{a}}$-deficient MCF-10A cells, even in an impaired p53 background, cannot withstand short periods of acute telomere damage and are designated to stop proliferation and die.

\section{DISCUSSION}

In human primary cells replication-dependent telomere attrition leads to the accumulation of dysfunctional telomeres, which have been recognised 
to play a relevant role in controlling the proliferative boundaries and fate of human cells. It is known that cells containing fewer than five dysfunctional telomeres can proliferate without halting the cell cycle [51], but above this threshold, cells enter senescence. Hence, the natural ends of chromosomes function as tumour suppressors by limiting the outgrowth of incipient tumour cells. At this point, full deprotection of telomeres is not occurring, as

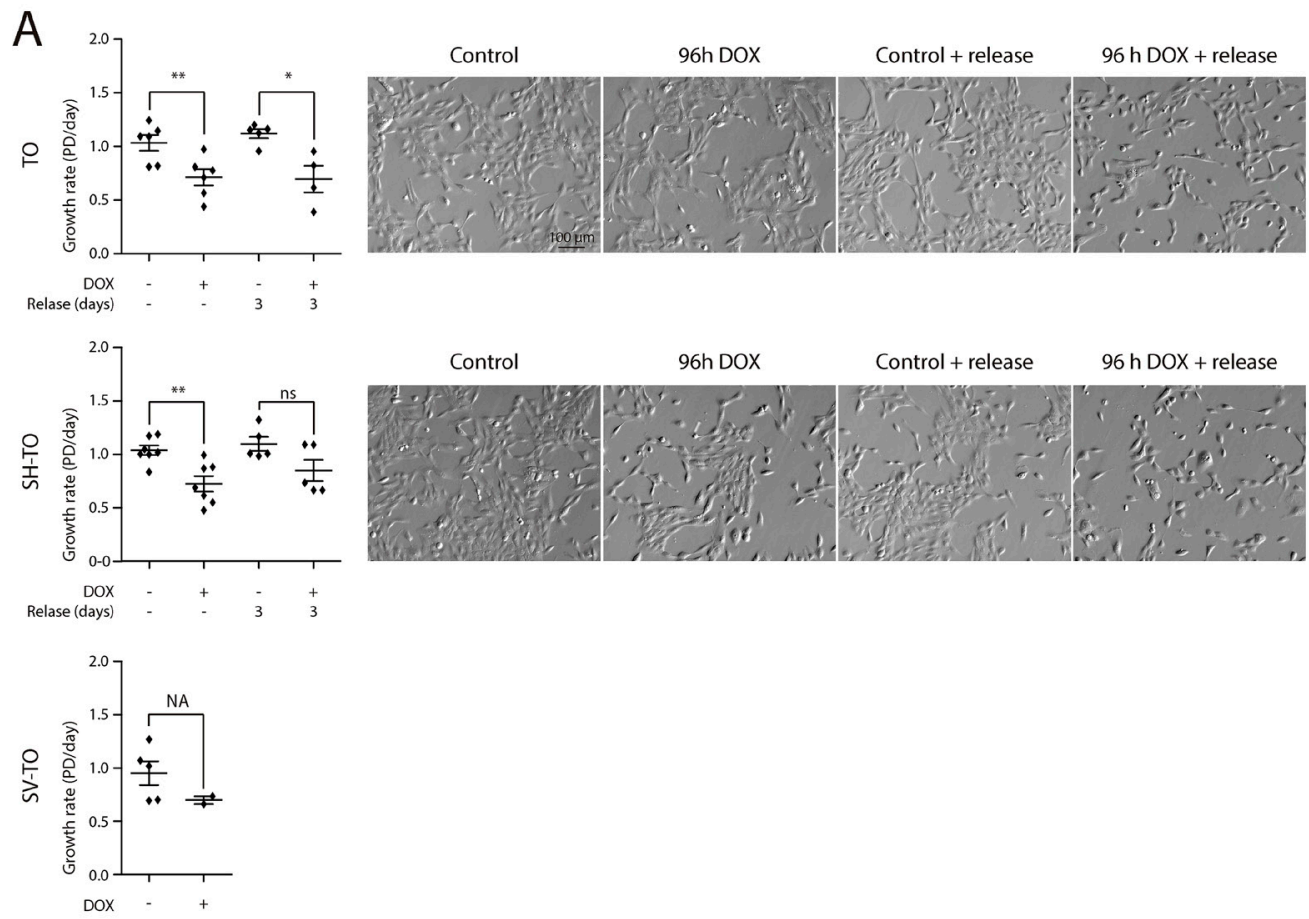

B
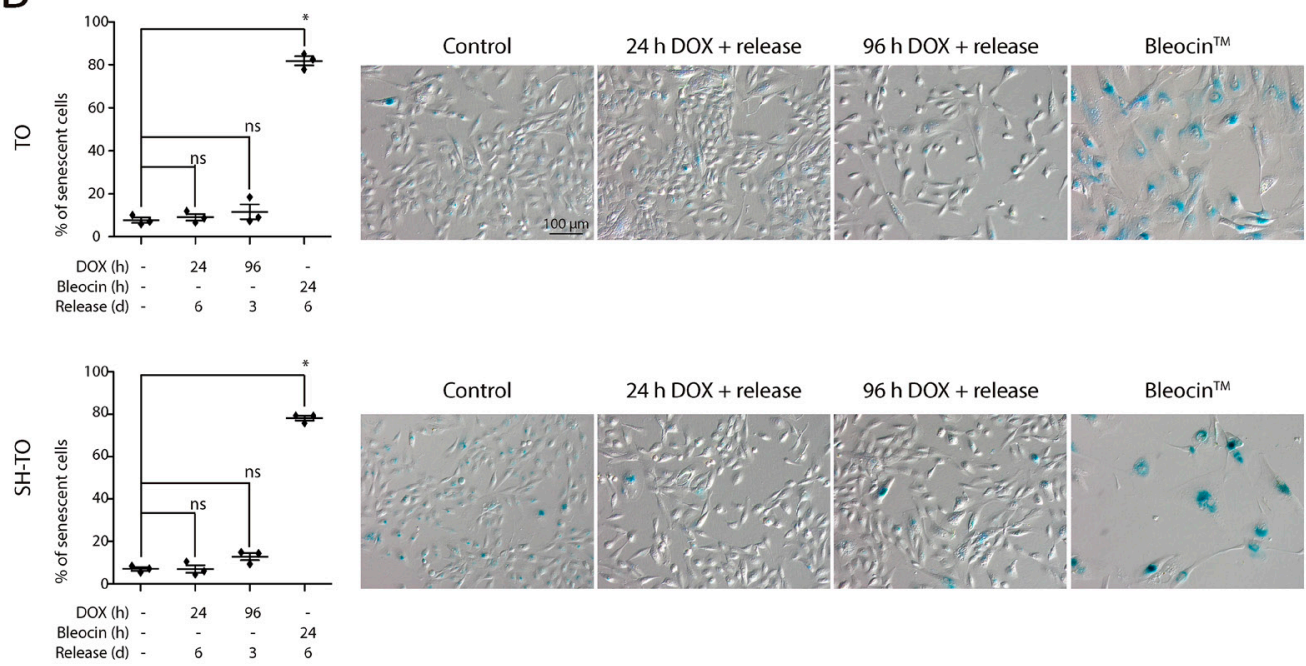

Figure 6: Reduced growth of cells displaying acute telomere dysfunction in the absence of a senescent phenotype. (A) Growth rate experiments in the modified cell lines after $96 \mathrm{~h}$ DOX exposure or after three days release from exposure demonstrate a reduced proliferation of cells displaying uncapped telomeres (TO cell line: $96 \mathrm{~h}$ DOX $p=0.0087,96 \mathrm{~h}$ DOX and release $\mathrm{p}=0.0159$; SH-TO cell line: $96 \mathrm{~h}$ DOX $\mathrm{p}=0.0032,96 \mathrm{~h}$ DOX and release $\mathrm{p}=0.2222$ ). Analysis was performed from at least three independent experiments and analysed by Mann-Whitney test. Statistical analysis of SV-TO cells was not assessable (NA) due to the reduced number of replicates. At the right side, representative contrast field images of control and treated cells. Scale bar corresponds to $100 \mu \mathrm{m}$. (B) SA- $\beta$-galactosidase activity staining was analysed only in TO and SH-TO cell lines. The cells were exposed to $24 \mathrm{~h}$ or $96 \mathrm{~h}$ DOX and analysed after six or three day release, respectively. As positive control, the cells were treated with the DSBs-inducer Bleocin ${ }^{\mathrm{TM}}$ during $24 \mathrm{~h}$ and processed 6 days later. Analysis was performed on three replicates and Kuskal-Wallis test and Dunn's multiple comparison post-test. At the right side, representative bright field images of control and treated cells. Scale bar corresponds to $100 \mu \mathrm{m}$. 

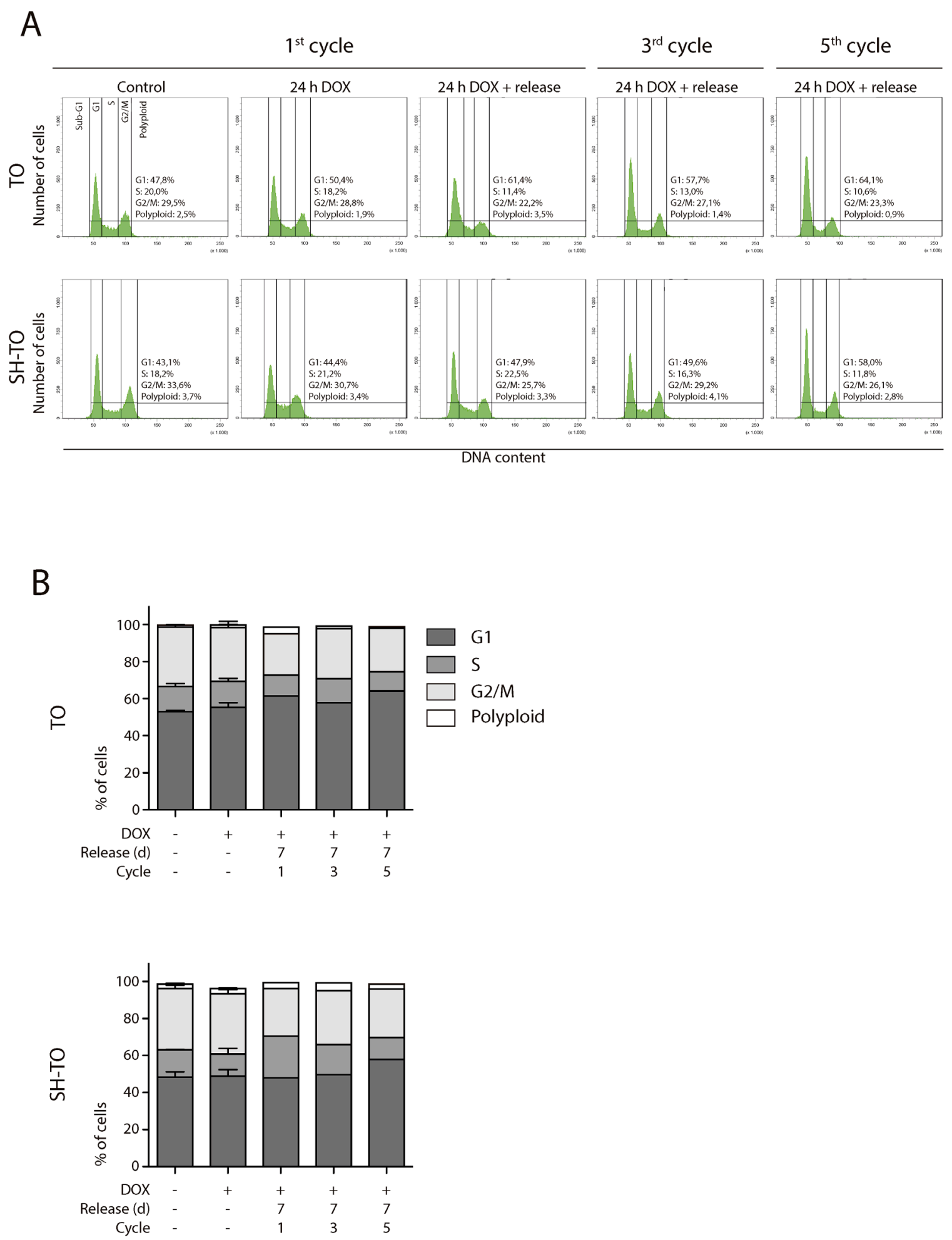

Figure 7: Short TRF2 $2^{\mathrm{ABAM}}$ expression periods did not alter the cell cycle profile. (A) Representative cell cycle profiles of TO and SH-TO cell lines after periods of short TRF $2^{\triangle \mathrm{B} \triangle \mathrm{M}}$ expression. The first column shows the control cells. Subsequent columns show $24 \mathrm{~h}$ of sustained DOX treatment, $24 \mathrm{~h}$ of DOX treatment and 7 days of release, from the first, third and fifth DOX cycle, respectively. Cell cycle profiles remain stable during $24 \mathrm{~h}$ of DOX treatment, as well after their release during five cycles of TRF $2^{\triangle \mathrm{B} \triangle \mathrm{M}}$ expression. Cell cycle phases are marked and values indicated. (B) Cell cycle phases distribution among TO and SH-TO cell lines after $24 \mathrm{~h} \mathrm{DOX}$ exposure experiments. No statistical differences were observed between control and DOX samples treated during $24 \mathrm{~h}$ (Mann-Whitney test). Data are presented as mean + SEM from three independent experiments, except for $24 \mathrm{~h}$ of DOX treatment and release of the first, the third and the fifth cycles, in which only one experiment is shown. A minimum of 10,000 cells were analysed per experiment. 
end-to-end chromosome fusions are not observed [51]. Circumvention of this growth arrest, in most human cells, needs combined inactivation of p53 and pRb pathways. Strikingly, primary HMECs cultured in vitro can avoid the M1 growth arrest by spontaneous silencing of the $C D K N 2 A$ gene through promoter hypermethylation [52, 53]. In the absence of $\mathrm{p} 16^{\mathrm{INK} 4 \mathrm{a}}$ expression, HMECs acquire an extended lifespan, where further telomere shortening results in the progressive transit of telomeres from a closed state to an uncapped state. As human telomeres are heterogeneously sized, physiological telomere erosion in vHMECs leads to the gradual appearance of unprotected telomeres that are continuously repaired by fusing with each other [5]. This reduces the initial damage and allows massive remodelling and scrambling of the genome through endless BFB cycles on proliferating cells (reviewed in [43]). Nevertheless, these proliferating unstable cells finally succumb to p53-dependent growth arrest, called agonescence, or crisis if p53 function is abrogated [54]. It is thought that stabilisation of telomere length in these genome unstable cells would alleviate DNA damage and rescue cellular fitness at a cost of driving to malignancy.

With the aim of generating immortal mammary cells that have passed through a period of telomere instability, we have set up a reversible system of acute telomere deprotection by controlling the expression of TRF2 ${ }^{\triangle \mathrm{B} \Delta \mathrm{M}}$ in the $\mathrm{p} 16^{\mathrm{INK} 4 \mathrm{a}}$-deficient MCF-10A breast epithelial cell line. We hypothesised that transient periods of telomere dysfunction through shelterin modification in telomerase
A

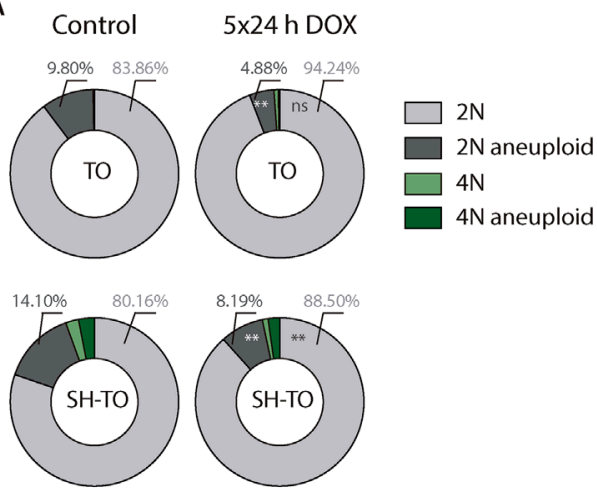

B
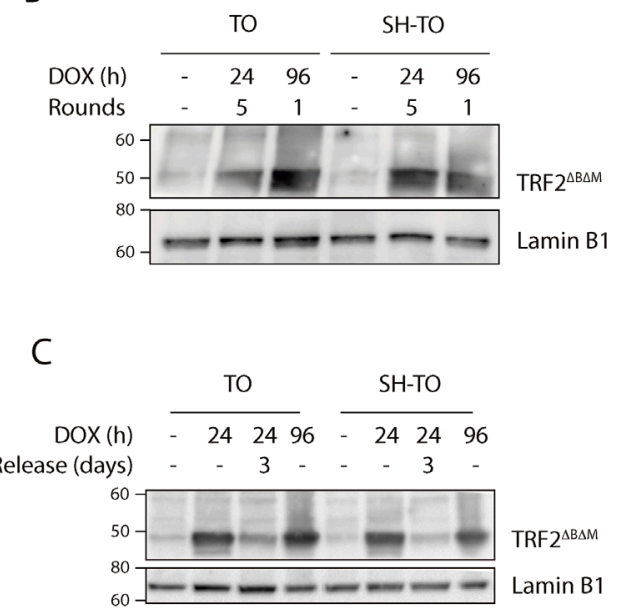

D

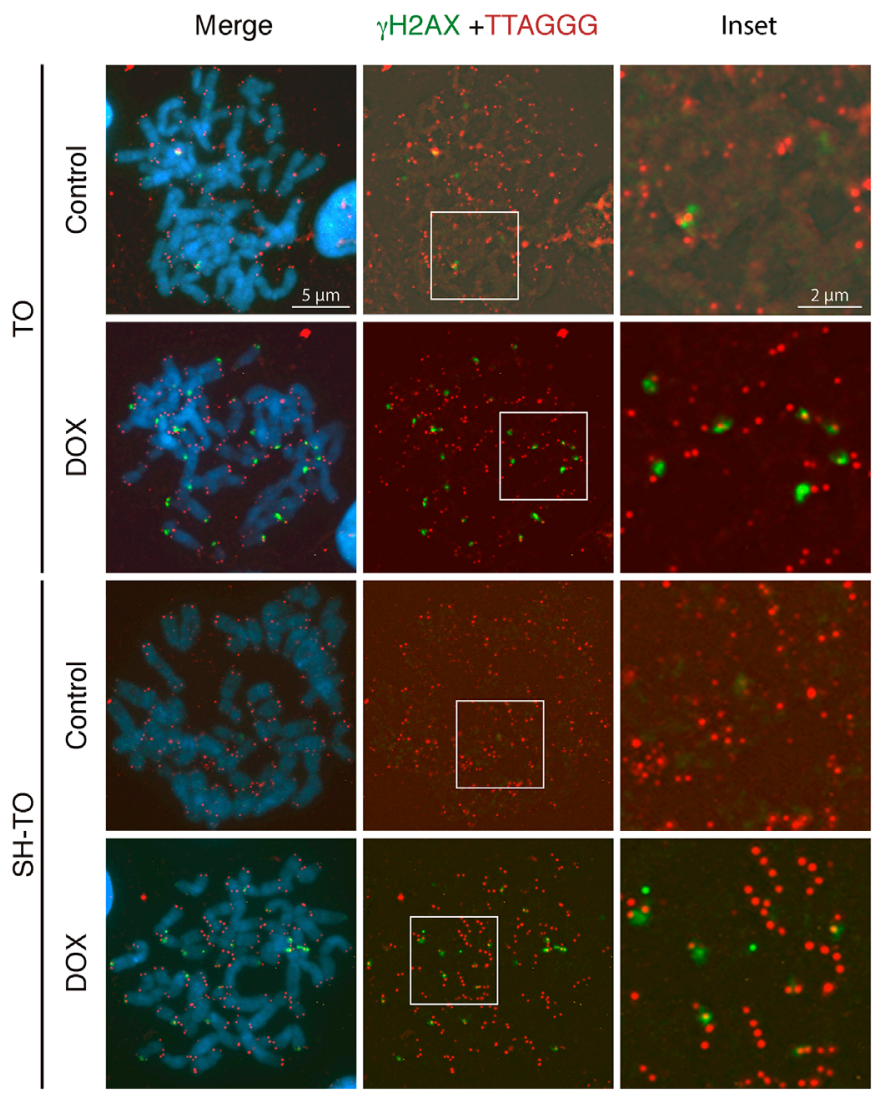

Figure 8: Short cycles of TRF2 $2^{\Delta \mathrm{BAM}}$ expression do not generate unstable cells. (A) Reduction in $2 \mathrm{~N}$-aneuploid cells in TO and SH-TO cell lines when repeated TRF2 $2^{\triangle \mathrm{B} \Delta \mathrm{M}}$ expression periods were induced ( $\mathrm{p}=0.0064$ and $\mathrm{p}=0.0036$, respectively). (B) Immunoblot of $\mathrm{TRF}^{\triangle \mathrm{B} \Delta \mathrm{M}}$ expression in TO and SH-TO cells denotes that the expression of TRF2 ${ }^{\triangle \mathrm{B} \Delta \mathrm{M}}$ was not diluted over time. Protein levels during the fifth $24 \mathrm{~h}$ DOX treatment were similar to those observed after $96 \mathrm{~h}$ of sustained acute telomere deprotection. Lamin B1 was used as loading control. (C) Immunoblot of TRF2 ${ }^{\triangle \mathrm{B} \triangle \mathrm{M}}$ expression after $24 \mathrm{~h}$ or $96 \mathrm{~h}$ of sustained DOX treatment and after 3 days of recovery from $24 \mathrm{~h}$ DOX in TO and SH-TO cell lines. Note that $24 \mathrm{~h}$ of DOX treatment was enough to induce the expression of TRF2 $2^{\Delta \mathrm{B} \Delta \mathrm{M}}$ and protein levels were similar between $24 \mathrm{~h}$ and $96 \mathrm{~h}$ of sustained TRF $2^{\triangle \mathrm{B} \Delta \mathrm{M}}$ expression. Three days after DOX removal, TRF2 ${ }^{\triangle \mathrm{B} \Delta \mathrm{M}}$ was still present but to a lesser extent. Lamin B1 was used as loading control. (D) Representative images of $\gamma \mathrm{H} 2 \mathrm{AX}$ foci (green) and telomere (red) PNA hybridisation in metaphase TO and SH-TO cells. TIFs were observed in both cell lines after $24 \mathrm{~h}$ of sustained DOX treatment. Insets indicate colocalisation of $\gamma \mathrm{H} 2 \mathrm{AX}$ foci and telomere DNA. Scale bar corresponds to $5 \mu \mathrm{m}$ in the images and to $2 \mu \mathrm{m}$ in the insets. 
proficient cells would drive BFB cycles and produce some degree of ongoing instability at a level compatible with cell viability. Our study demonstrates that controlled TRF2 depletion efficiently produced a telomere dysfunction phenotype in the modified MCF-10A cell lines. Nevertheless, we did not find clear evidence of ongoing BFB cycles, such as secondary chromosome aberrations with interstitial telomeric DNA sequences, increased aneuploid configurations in interphase nuclei or the accumulation of cells with 8C DNA content compatible with cycling polyploids. Despite the fact that the increased fraction of anaphase cells with chromatin bridges could reflect cell cycle progression, the lack of telomeredependent CIN somehow denotes the absence of long term proliferation of cells with telomere damage. Indeed, reduced cell growth was discernible in the modified cell lines exposed to TRF $2^{\triangle \mathrm{B} \Delta \mathrm{M}}$. But the proliferation defects were not accompanied by cell cycle disturbances or visible markers of senescence or apoptosis. What is more, $96 \mathrm{~h}$ of telomere dysfunction did not precipitate a DDR comparable to the one elicited by the DSBs-inducer Bleocin $^{\mathrm{TM}}$. The low level of DNA damage inflicted after TRF2 depletion could be the reason for the ambiguous disappearance of cells carrying telomere damage. Thus, it seems likely that $\mathrm{TRF} 2^{\triangle \mathrm{B} \Delta \mathrm{M}}$ expression induces proliferation defects in $\mathrm{p} 16^{\mathrm{INK} 4 \mathrm{a}}$-deficient MCF-10A breast epithelial cells that conclude in their clearance from the cell culture, presumably because of a telomere capping defect rather than cell death associated with telomeredependent extensive genome instability.

In contrast to progressive telomere shortening, the expression of TRF2 $2^{\triangle \mathrm{B} \Delta \mathrm{M}}$ suddenly evokes the direct transition of several telomeres from a closed to a deprotected state $[27,55]$. In primary fibroblasts, the cellular response to $\mathrm{TRF}^{\triangle \mathrm{B} \Delta \mathrm{M}}$ expression somehow recapitulates telomere-dependent replicative senescence, but cells stop division, displaying telomere-to-telomere fusions, chromatin bridges at anaphase, and nearly tetraploid karyotypes [20, 22, 23]. The growth arrest imposed by TRF2 deletion in primary fibroblasts is overridden by combined inactivation of p53 and pRb pathways through SV40LT [20] or HPV16 E6E7 [56] infection. Also, when $\mathrm{p} 16^{\mathrm{INK} 4 \mathrm{a}}$ inhibition is combined with p53 inactivation, a nearly complete bypass of telomereinduced senescence is achieved [48]. Even though, the telomere damage inflicted results, in all instances, in lethal genome instability $[20,48,56]$. Unlike fibroblasts, the proliferation restraint elicited by sustained TRF $2^{\triangle \mathrm{B} \Delta \mathrm{M}}$ expression in $\mathrm{p} 16^{\mathrm{INK} 4 \mathrm{a}}$-deficient MCF-10A cells was not circumvented by short hairpin p53 inactivation, thus revealing a distinct cellular response of the mammary epithelial lineage to TRF2 depleted telomeres. Such cell lineage discrepancy was probably not related to the intensity of the telomere damage inflicted, as the rate of cells containing end-to-end fusions and the frequency of end fusions per cell were similar between the Jacobs and de Lange study and the results presented herein [48]. The most likely interpretation is that epithelial cells showing p16 ${ }^{\mathrm{INK} 4 \mathrm{a}}$ deficiencies are highly sensitive to acute DNA damage derived from sustained TRF $2^{\triangle \mathrm{B} \Delta \mathrm{M}}$ expression and are committed to stop proliferating and probably die. This assumption is also reinforced by the presence of metaTIFs after $24 \mathrm{~h}$ TRF $2^{\triangle \mathrm{B} \Delta \mathrm{M}}$ expression and by the karyotype analysis of cells retrieved after transient periods of short $\mathrm{TRF}^{\mathrm{AB} \Delta \mathrm{M}}$ expression. The reduction in the telomere insult to shorter periods again demonstrated a lack of hallmarks compatible with ongoing BFB cycles. Altogether, these data suggest that even brief TRF2 depletion periods in $\mathrm{p} 16^{\mathrm{INK} 4 \mathrm{a}}$-deficient $\mathrm{MCF}-10 \mathrm{~A}$ cells leads to a level of telomere damage that is incompatible with cell proliferation, and supports the view that the telomere insult itself, and not the genomic instability associated with BFB cycles, is responsible for the deleterious effects on cell proliferation [57].

In summary, the severity of the cellular responses to progressive or acute telomere dysfunction are not analogous among mammary epithelial cells and seems to be dependent on the severity of the telomere damage impinged. p16 ${ }^{\mathrm{INK} 4 \mathrm{a}}$-deficient breast epithelial cells react to the minor damage of progressive telomere uncapping by stimulating repair and cell survival at a cost of unleashing genome instability through the onset of BFB cycles [43]. Conversely, TRF2-depleted telomeres in p16 ${ }^{\mathrm{INK} 4 \mathrm{a}}$-deficient mammary MCF-10A cells results in a proliferative block that prevents the generation of genome unstable cells. This halt in cell cycle progression is not due to the sustained telomere damage, as even transient cycles of short TRF2 deprotection were unable to drive chromosome instability. We propose that the deprotection of many telomeres simultaneously, above a certain DNA damage threshold, probably results in a local activation of the cellular stress response that consequently triggers cell withdrawal from cell cycle to maintain genomic integrity.

\section{MATERIALS AND METHODS}

\section{Cell lines}

Non-transformed human mammary epithelial MCF-10A cells, provided by Dr Carme Nogués, and derived cell lines were cultured in DMEM:F12 (GIBCO, ThermoFisher Scientific) supplemented with $2 \%$ tetracycline-free horse serum (GIBCO), cholera toxin (100 ng/ml) (Sigma-Aldrich), hEGF (20 ng/ml) (SigmaAldrich), hydrocortisone $(0.5 \mu \mathrm{g} / \mathrm{ml})$ (Sigma-Aldrich), insulin $(10 \mu \mathrm{g} / \mathrm{ml})$ (Sigma-Aldrich) and 1\% penicillin/ streptomycin (GIBCO). Post-stasis variant human mammary epithelial cells (vHMECs) were obtained from Cell Applications Inc. (San Diego, CA, USA). Pre-stasis HMECs were established from reduction mammoplasty tissue in accordance with previously reported methods [58]. The patient signed a written consent form allowing 
their tissue to be used for biological research; this consent was obtained by the medical staff at the hospital prior to surgery. All work with human derived material was reviewed and approved by the Human Subjects Protection Committee of the Universitat Autònoma de Barcelona. vHMECs and HMECs were cultured with serum-free MEpiCM medium supplemented with MEpiCGS and penicillin/streptomycin (all from ScienCell Research Laboratories, Carlsbad, CA, USA), or with M87AX [59]. HEK 293 T cells were cultured in DMEM (GIBCO) supplemented with $10 \%$ of foetal bovine serum (GIBCO) and $1 \%$ of penicillin/streptomycin.

Growth conditions were $5 \% \mathrm{CO}_{2}$ and $37^{\circ} \mathrm{C}$. Culture population doublings (PDs) were calculated using the formula: $\mathrm{PD}=\mathrm{PD}_{\text {initial }}+\log _{2}\left(\mathrm{~N}_{\text {final }} / \mathrm{N}_{\text {initial }}\right)$, where $\mathrm{N}_{\text {initial }}$ is the number of viable cells plated, and $\mathrm{N}_{\text {final }}$ is the number of viable cells harvested.

\section{Lentiviral vectors}

A lentiviral tetracycline-inducible $T R F 2^{\Delta \mathrm{B} \Delta \mathrm{M}}$ construct was generated by cloning the inducible TRF $2^{\triangle \mathrm{B} \Delta \mathrm{M}}$ cassette from a pBluescript.KS vector (courtesy of Dr Lenhard Rudolph) into a neomycin resistant promoterless lentivector (Amsbio) using X-baI restriction sites. The Tet-regulated transcriptional transactivator protein rtTA3 containing hygromycin resistance was a kind gift from Dr Iain Fraser. The lentiviral construct for p53 short hairpin RNA (shp53 pLKO.1 puro) was from Dr Bob Weinberg (Addgene plasmid \#19119), and the lentiviral plasmid for SV40LT (pRRLsin-SV40 T antigen-IRES-mCherry) was from Dr Snorri Thorgeirsson (Addgene plasmid \#58993). The hTERT lentivirus was supplied by Viral Vector Facility, CNIC, Spain.

\section{Lentivirus production and transduction}

To generate lentiviral particles, the psPAX2 and pMD2.G plasmids together with the plasmid containing the gene of interest were introduced in HEK 293T packaging cells using Calphos Mammalian Transfection kit (Clontech). Supernatants were collected at 48 and $72 \mathrm{~h}$ post-transfection and concentrated using Amicon 100,000 centrifugal filter units (Merck-Millipore).

The MCF-10A T/O TRF2 ${ }^{\triangle \mathrm{B} \Delta \mathrm{M}}$ (TO) cell line was generated by lentiviral transduction of MCF-10A cells with the TRF $2^{\triangle \mathrm{B} \Delta \mathrm{M}}$ inducible cassette and the rtTA3 transactivator, with polybrene $(4 \mu \mathrm{g} / \mathrm{ml})$ (Sigma-Aldrich). Transduced cells were selected first with G418 (300 $\mu \mathrm{g} /$ $\mathrm{ml}$ ) (Sigma-Aldrich) and afterwards with hygromycin (300 $\mu \mathrm{g} / \mathrm{ml}$ ) (Sigma-Aldrich). The MCF-10A T/O TRF2 $2^{\Delta \mathrm{B} \Delta \mathrm{M}}$ SHP53 (SH-TO) was generated by lentiviral transduction of shp53 and selection with puromycin $(0.75 \mu \mathrm{g} / \mathrm{ml})$. The MCF-10A T/O TRF2 ${ }^{\Delta \mathrm{B} \Delta \mathrm{M}}$-SV40LT (SV-TO) cell line was generated by transduction of MCF-10A T/O TRF2 ${ }^{\Delta \mathrm{B} \Delta \mathrm{M}}$ with SV40LT-mCherry lentiviral particles. Selection of the different transduced cells was performed through one week culture with the appropriate antibiotic or, in the case of SV-TO cells, through FACS sorting of mCherry positive cells.

vHMECs expressing hTERT (vHMEC-hTERT) were generated by lentiviral transduction of vHMECs with the hTERT lentivirus at PD 21. HMECs-hTERT expressing SV40LT were generated by lentiviral transduction of SV40LT-mCherry lentiviral particles at passage 2 (PD 6.92).

\section{Expression of TRF $2^{\Delta \mathrm{B} \Delta M}$}

Induction of telomere dysfunction in the different conditional cell lines was performed by culturing the cells with regular MCF-10A medium containing $1 \mu \mathrm{g} / \mathrm{ml}$ doxycycline (DOX) (Sigma-Aldrich). Long-term telomere dysfunction experiments consisted of the persistent exposure of cells to DOX for $96 \mathrm{~h}$. In all experiments, fresh DOX was added to the cell culture each $48 \mathrm{~h}$. Moreover, conditional studies were conducted where telomere dysfunction was switched on and switched off by the addition/removal of DOX from the culture medium. Long-term exposure cycles consisted of $96 \mathrm{~h}$ of sustained $\mathrm{TRF}^{\mathrm{AB} \triangle \mathrm{M}}$ expression and 3 days without DOX, whereas in short-term cycles, cells where treated with DOX for $24 \mathrm{~h}$ and then were exposed to DOX-free medium for 7 days.

\section{Western blotting}

Proteins were extracted with 2\% SDS, $67 \mathrm{mM}$ Tris $\mathrm{HCl}(\mathrm{pH}$ 6.8) or RIPA lysis buffer, containing protease and phosphatase inhibitors. Protein extracts were sonicated twice at $25 \%$ amplitude for $15 \mathrm{~s}$, boiled at $95^{\circ} \mathrm{C}$ for 15 min and centrifuged at 20,000 $\mathrm{g}$ for $10 \mathrm{~min}$. Proteins were quantified using the BCA method and absorbance was read at $540 \mathrm{~nm}$ with a Victor3 spectrophotometer (PerkinElmer). The proteins $(30 \mu \mathrm{g})$ were separated using 3-8\% Tris-acetate or 10\% Bis-Tris gels (Life Technologies, ThermoFisher Scientific) at $35 \mathrm{mAmp}$ and transferred onto nitrocellulose or PVDF membranes at $30 \mathrm{~V}$. Membranes were blocked with $5 \%$ non-fat milk or BSA. Primary antibodies used were: mouse anti-SV40 st+LT Ag (Santa Cruz; sc-148), rabbit anti-pRb ${ }^{\mathrm{S} 807 / 811}$ (Cell Signaling; D20B12), mouse anti-pRB (Cell Signaling; 4H1), rabbit anti-p53 ${ }^{\mathrm{S} 15}$ (ThermoFisher Scientific, 14H61L24), mouse anti-p53 (ThermoFisher Scientific, DO-1), mouse anti$\gamma \mathrm{H} 2 \mathrm{AX}$ (Upstate; 07-164), rabbit anti-p21 ${ }^{\mathrm{Waf1} / \mathrm{Cip} 1}$ (Cell Signaling; 12D1) and mouse anti-TRF2 (Novus Biologicals; 4A794.15). Furthermore, mouse anti- $\alpha$-Tubulin (Sigma, B-5-1-2) and rabbit anti-lamin B1 (Abcam; ab16048) were used as loading controls. Primary antibodies were incubated overnight at $4^{\circ} \mathrm{C}$. Secondary anti-mouse or antirabbit horseradish peroxidase (HRP) conjugated antibodies were used and incubated for $1 \mathrm{~h}$ at room temperature. Chemiluminescent detection was performed using HRP 
solution and luminol (Life Technologies), and images were acquired using Chemidoc, processed with Quantity One software and analysed with ImageLab ${ }^{\mathrm{TM}}$ 6.0.0 (BioRad).

\section{Drug treatments}

DSBs were generated in MCF-10A and derivatives through exposure to the radiomimetic drug Bleocin $^{\mathrm{TM}}$ (Calbiochem, Merck-Chemicals; Germany), a bleomycin compound, at a final concentration of 2.5 $\mu \mathrm{g} / \mathrm{ml}$. The drug was washed out after $1 \mathrm{~h}$ exposure and the cells were left to recover for $60 \mathrm{~min}$ before protein extraction.

Colcemid (GIBCO) at a final concentration of 50 $\mathrm{ng} / \mathrm{ml}$ was added to asynchronously proliferating $\mathrm{TO}, \mathrm{SH}-$ $\mathrm{TO}$ and SV-TO cells. After $24 \mathrm{~h}$ of colcemid exposure, the cells were collected and fixed in 70\% ethanol and kept frozen until FACS processing. Additional experiments consisted of $24 \mathrm{~h}$ colcemid treatment, washout and $24 \mathrm{~h}$ or $48 \mathrm{~h}$ release before fixation.

\section{Obtaining metaphase cells and end-to-end fusion scoring criteria}

Exponentially growing MCF-10A and, untreated and doxycycline-treated MCF-10A modified cell lines were exposed to colcemid $(0.5 \mu \mathrm{g} / \mathrm{ml})$ for $2 \mathrm{~h}$. Cells were trypsinised, swollen in $0.075 \mathrm{M} \mathrm{KCl}$ and fixed in methanol:acetic acid (3:1). Cell suspensions were dropped onto clean slides and stored at $-20^{\circ} \mathrm{C}$ until use. For endfusion scoring purposes, slides were first stained with DAPI. Then, the metaphase plates were captured and the karyotype was performed by reverse DAPI staining, which results in a reproducible $\mathrm{G}$ band-like pattern that allows for accurate individual chromosome identification before the chromosomes became swollen by the denaturation step. Afterwards, the slides were hybridised with the PNA probes and the metaphases were relocated to analyse the telomere and centromere status of each chromosome. A fusion event was considered when the connection between chromatids (1 or 2) was verified on the initial DAPI stained image. This procedure reduces the possibility of end-fusions events being confused with mere alignment of chromosomes.

\section{In situ fluorescence hybridisation}

\section{Telomere and centromere PNA-FISH}

Metaphase spreads were hybridised with pantelomeric (Rho-(CCCTAA), PE Biosystems) and pancentromeric (FITC-AAACACTCTTTTTGTAGA, Panagene) PNA probes. Denaturation took place at $80^{\circ} \mathrm{C}$ for $3 \mathrm{~min}$ and hybridisation was performed at $37^{\circ} \mathrm{C}$ for $2 \mathrm{~h}$ in a humid chamber. Afterwards, slides were washed twice with $70 \%$ formamide for $15 \mathrm{~min}$, followed by three TNT (Trizma Base $50 \mathrm{mM}, \mathrm{NaCl} 150 \mathrm{mM}$ and Tween20 0.25\%) washes for 5 min. Dehydrated slides were counterstained with DAPI.

\section{OligoFISH}

Interphase nuclei spreads were treated with pepsin$\mathrm{HCl}$ at $37^{\circ} \mathrm{C}$ for $10 \mathrm{~min}$, post-fixed with formaldehyde$\mathrm{MgCl}_{2}$ and denatured with $70 \%$ formamide at $74^{\circ} \mathrm{C}$. Specific centromeric probes for chromosomes 6 (Gold DY539), 12 (Red DY590) and 17 (Green DY490) (Cellay, Inc.) were hybridised for $2 \mathrm{~h}$ in a humid chamber followed by one 5 min wash with $0.2 \times S S C-0.1 \% \mathrm{SDS}$ at $50^{\circ} \mathrm{C}$ and a $2 \times \mathrm{xSC}$ wash. Cells were dehydrated and counterstained with DAPI.

\section{DAPI staining, immunofluorescence and TIFs (telomere dysfunction induced foci)}

For anaphase bridge scoring, cells cultured on coverslips were fixed with $4 \%$ paraformaldehyde (PFA) at $37^{\circ} \mathrm{C}$, rinsed twice in PBS, allowed to dry and counterstained with DAPI.

For immunofluorescence, cells were fixed in $4 \%$ PFA for $10 \mathrm{~min}$ at $37^{\circ} \mathrm{C}$, permeabilised with $1 \%$ Triton $\mathrm{X}-100$ at room temperature and blocked with 5\% FBS$0.1 \%$ Triton X-100- KCM buffer. Then SV40 st+LT Ag (1:200) primary mouse antibody was incubated overnight at $4^{\circ} \mathrm{C}$. Conjugated chicken Alexa Fluor 488 -antimouse antibody (1:500, ThermoFisher Scientific) was incubated for $1 \mathrm{~h}$. Cells were counterstained with DAPI.

For the TIF assay, cells were treated with DOX for $24 \mathrm{~h}$. The following day, chromosome spreads were obtained as described by [60]. Briefly, after $25 \mathrm{~min}$ of colcemid $(20 \mathrm{ng} / \mathrm{ml})$, the cells were trypsinised and resuspended to a final concentration of $5 \times 10^{4}$ cells $/ \mathrm{ml}$ in hypotonic solution $(0.2 \%$ Trisodium Citrate- $0.2 \%$ $\mathrm{KCl})$. Thereafter, the cells were cytocentrifuged $10 \mathrm{~min}$ at $1,000 \mathrm{rpm}$ and the slides were air dried. Afterwards, the slides were treated with pre-extraction buffer for 5 min, $1 \%$ Triton X-100- KCM buffer for $10 \mathrm{~min}$ and fixed with $4 \%$ PFA for 10 min. Permeabilisation was also performed with chilled absolute methanol during 20 min. Cells were blocked with $2 \%$ FBS- $0.1 \%$ Triton $\mathrm{X}-100-100 \mu \mathrm{g} / \mathrm{ml}$ RNAse- TrisNaCl for $30 \mathrm{~min}$ at $37^{\circ} \mathrm{C}$, and mouse anti- $\gamma \mathrm{H} 2 \mathrm{AX}(1: 500$, clone JBW301 Millipore) antibody was incubated at $4^{\circ} \mathrm{C}$. Conjugated chicken Alexa Fluor 488-antimouse was incubated for $1 \mathrm{~h}$. Slides were fixed again in 2\% PFA for $10 \mathrm{~min}$ and dehydrated through an ethanol series. Samples and

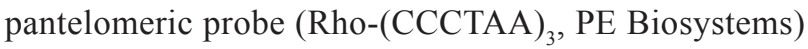
were co-denatured at $80^{\circ} \mathrm{C}$ for $4 \mathrm{~min}$, and hybridised overnight at $37^{\circ} \mathrm{C}$ in a humid chamber. Slides were washed once with $70 \%$ formamide-Tris and twice with PBST. To ensure $\gamma \mathrm{H} 2 \mathrm{AX}$ staining, conjugated Alexa Fluor 488-antimouse was re-incubated for $30 \mathrm{~min}$. Cells were dehydrated and counterstained with DAPI.

\section{Fluorescent microscopy and fluorescent images}

Most fluorescent staining was visualised under an Olympus BX60 microscope equipped with epifluorescent 
optics and a camera (Applied Imaging, Inc.). In the case of TIFs analysis, an Olympus BX61 epifluorescence microscope with motorized $x-y$ stage (BX-UCB, Olympus) was used to acquire images as a Z-stack (total of 7 planes of $2.11 \mu \mathrm{m}$ each). The fluorochromes were visualised through simple filters and images were captured and analysed using Cytovision software (Applied Imaging, Inc.).

\section{Flow cytometry and live cell sorting}

For tracking S phase cells, a pulse of $10 \mu \mathrm{M}$ BrdU was carried out for 30 minutes. Afterwards, the cells were rinsed, trypsinised, centrifuged and fixed with $70 \%$ ethanol. For cell cycle analysis or SV40 st+LT detection, the cells were harvested and fixed in 70\% ethanol and kept at $-20^{\circ} \mathrm{C}$ until processing.

For SV40 st+LT and BrdU analysis, the fixed cells were permeabilised with $1 x P B S-1 \%$ Triton X-100 solution. In the case of BrdU detection, DNA was denatured with $\mathrm{HCl} 2 \mathrm{~N}-0.1 \%$ Triton X-100. After $30 \mathrm{~min}$, denaturation was blocked by adding tetraborate solution $(0.1 \mathrm{M})$. Before antibody detection, every sample was divided into two tubes, one for mouse anti-SV40 st+LT Ag (Santa Cruz; sc-148) or mouse anti-BrdU (Santa Cruz, sc32323) and subsequent Alexa Fluor 488-antimouse secondary antibody. The second tube was used as a negative control of the secondary antibody.

All cells were stained with propidium iodide solution (PBS-1\% Triton X-100, propidium iodide $45 \mu \mathrm{g}$ / $\mathrm{ml}$, and RNase $0.2 \mathrm{mg} / \mathrm{ml}$ ) before cytometric processing. Analysis was performed under a FACSCalibur (Beckton Dickinson). Sample excitation was done with a $488 \mathrm{~nm}$ laser and a minimum of 10,000 events were collected per sample. Single cells were gated first by forward scatter (FSC) and side scatter (SSC), and DNA content of single cells was measured on FL3 (670 nm long pass filter) and plotted vs. number of cells. Alternatively, A488 fluorescence was detected on FL1 (530/30 nm band pass filter) and was plotted vs. propidium iodide. The data were analysed with BD FACSDiva software v7.0.

For live cell experiments, cells were trypsinised and resuspended in PBS. Sorting of mCherry positive cells was carried out using a FACSAria I SORP sorter (Beckton Dickinson). Excitation of the sample was done using a 488 $\mathrm{nm}$ laser for FSC and green fluorescence parameters, and a $561 \mathrm{~nm}$ laser was used for the excitation of mCherry and SSC signals. Cells were gated according to their FSC vs. SSC parameters. Red emission from mCherry (610/20 $\mathrm{nm})$ excited with the yellow laser $(561 \mathrm{~nm})$ was plotted vs. green emission $(530 / 30 \mathrm{~nm})$ from the $488 \mathrm{~nm}$ laser on a dot plot in order to discriminate mCherry positive cells.

\section{Senescence associated beta-galactosidase staining}

TO and SH-TO cells treated with DOX $(1 \mu \mathrm{g} / \mathrm{ml})$ for $24 \mathrm{~h}$ and $96 \mathrm{~h}$ and left to recover until the seventh day were seeded at a concentration of 7,500 cells/well. A positive control consisted of cells treated with Bleocin ${ }^{\mathrm{TM}}$ $(2.5 \mu \mathrm{g} / \mathrm{ml})$ for $24 \mathrm{~h}$ and left to recover until the seventh day. In Bleocin ${ }^{\mathrm{TM}}$ experiments 50,000 cells/well were seeded. The Senescence $\beta$-Galactosidase Cell Staining Kit (Cell Signaling) was used according to the manufacturer's instructions. The cells were examined under a light microscope (Olympus IX71) and those cells with blue staining were considered positive for $\beta$-galactosidase activity. We estimated the percentage of $\beta$-galactosidase staining by analysing 5 individual fields per well from three replicates.

\section{Statistical analysis}

Data analysis was carried out with GraphPad Prism version 5 software (GraphPad Software Inc.). Normality distribution was tested by Saphiro-Wilk normality test. Data sets were compared using Fisher's exact test, MannWhitney test, Kruskal-Wallis test and Dunn's multiple comparison post-test. P-values less than 0.05 were considered significant. When multiple comparisons were done, the Bonferroni p-value correction was applied and indicated.

\section{Abbreviations}

$$
\begin{aligned}
& \text { ALT-pathway - Alternative Lengthening of } \\
& \text { Telomeres pathway } \\
& \text { BFB - Breakage Fusion Bridge } \\
& \text { BrdU - 5-bromo-2'deoxyUridine } \\
& \text { CDKN2A - Cycling Dependent Kinase Inhibitor 2A } \\
& \text { CIN - Chromosome INstability } \\
& \text { DAPI - 4',6-diamidino-2-phenylindole } \\
& \text { DCIS - Ductal Carcinoma In Situ } \\
& \text { DDR - DNA Damage Response } \\
& \text { DOX - Doxycycline } \\
& \text { DSB - Double Strand Break } \\
& \text { hEGF - human Epidermal Growth Factor } \\
& \text { HMEC - Human Mammary Epithelial Cell } \\
& \text { NRT - Non Reciprocal Translocation } \\
& \text { PD - Population Doubling } \\
& \text { Rho - Rhodamine } \\
& \text { TIF - Telomere-dysfunction Induced Foci } \\
& \text { TRF2 - Telomere Repeat binding Factor } 2 \\
& \text { vHMEC - variant Human Mammary Epithelial Cell }
\end{aligned}
$$

\section{Author contributions}

$\mathrm{AB}$ participated in study design, performed most of the experimental work, analysed the data, drafted the manuscript and critically reviewed it. MMA contributed to the experimental work and to data interpretation. DD contributed to study design, performed part of the experimental work, interpreted the data, and critically revised the manuscript. LT conceived and designed the study, performed part of the experimental work, 
interpreted the data, co-drafted and critically reviewed the manuscript. All authors read and approved the final manuscript.

\section{ACKNOWLEDGMENTS}

We gratefully acknowledge Lenhard Rudolph and André Lechel (Leibniz Institute on Ageing-Fritz Lipmann Institute, Jena, Germany) for the inducible construct and their invaluable help; Iain Fraser (Laboratory of Systems Biology, NIAID, Bethesda, USA) for the rttA3 plasmid; Joan Aurich-Costa (Cellay, Inc; Cambridge, USA) for providing us with oligoFISH probes; Carme Nogués (Universitat Autònoma de Barcelona) for the MCF10 A cell line; Jordi Surrallés's Laboratory (Universitat Autònoma de Barcelona) for technical assistance; and the services from the Universitat Autònoma de Barcelona (SCAC_Unitat de Cultius $i$ de Citometria) and the Universitat de Barcelona (CCiT_Servei de Citometria).

\section{CONFLICTS OF INTEREST}

The authors declare that they have no conflicts of interest.

\section{FUNDING}

This work was funded by MINECO (SAF201343801-P). The Cell Biology Unit is supported by Generalitat de Catalunya (2014SGR-524). AB and DD were supported by a Universitat Autònoma de Barcelona fellowship (456-01-1/2012) and Generalitat de Catalunya fellowship (2013FI_B200188), respectively.

\section{REFERENCES}

1. Griffith JD, Comeau L, Rosenfield S, Stansel RM, Bianchi A, Moss H, De Lange T. Mammalian telomeres end in a large duplex loop. Cell. 1999; 97:503-14. https://doi. org/10.1016/S0092-8674(00)80760-6.

2. Stansel RM, De Lange T, Griffith JD. T-loop assembly in vitro involves binding of TRF2 near the 3 ' telomeric overhang. EMBO J. 2001; 20:5532-40. https://doi. org/10.1093/emboj/20.19.5532.

3. Lazzerini-Denchi E, Sfeir A. Stop pulling my strings what telomeres taught us about the DNA damage response. Nat Rev Mol Cell Biol. 2016; 17:364-78. https://doi. org/10.1038/nrm.2016.43.

4. Counter CM, Avilion AA, Lefeuvrel CE, Stewart NG, Greider CW, Harley CB, Bacchettil S. Telomere shortening associated with chromosome instability is arrested in immortal cells which express telomerase activity. EMBO J. 1992; 11:1921-29.

5. Soler D, Genescà A, Arnedo G, Egozcue J, Tusell L. Telomere dysfunction drives chromosomal instability in human mammary epithelial cells. Genes Chromosomes Cancer. 2005; 44:339-50. https://doi.org/10.1002/gcc.20244.

6. Pampalona J, Soler D, Genescà A, Tusell L. Whole chromosome loss is promoted by telomere dysfunction in primary cells. Genes Chromosomes Cancer. 2010; 49:36878. https://doi.org/10.1002/gcc.

7. Maciejowski J, de Lange T. Telomeres in cancer: tumour suppression and genome instability. Nat Rev Mol Cell Biol. 2017; 18:175-86. https://doi.org/10.1038/nrm.2016.171.

8. Meeker AK, Hicks JL, Platz EA, March GE, Bennett CJ, Delannoy MJ, De Marzo AM. Telomere shortening is an early somatic DNA alteration in human prostate tumorigenesis. Cancer Res. 2002; 62:6405-9.

9. Meeker AK, Hicks JL, Iacobuzio-Donahue CA, Montgomery EA, Westra WH, Chan TY, Ronnett BM, De Marzo AM. Telomere length abnormalities occur early in the initiation of epithelial carcinogenesis. Clin Cancer Res. 2004; 10:3317-26. https://doi.org/10.1158/1078-0432. CCR-0984-03.

10. Meeker AK, Hicks JL, Gabrielson E, Strauss WM, De Marzo AM, Argani P. Telomere shortening occurs in subsets of normal breast epithelium as well as in situ and invasive carcinoma. Am J Pathol. 2004; 164:925-35. https://doi. org/10.1016/S0002-9440(10)63180-X.

11. Poonepalli A, Banerjee B, Ramnarayanan K, Palanisamy N, Putti TC, Hande MP. Telomere-mediated genomic instability and the clinico-pathological parameters in breast cancer. Genes Chromosomes Cancer. 2008; 47:1098-109. https://doi.org/10.1002/gcc.20608.

12. Simpson K, Jones RE, Grimstead JW, Hills R, Pepper C, Baird DM. Telomere fusion threshold identifies a poor prognostic subset of breast cancer patients. Mol Oncol. 2015; 9:1186-93. https://doi.org/10.1016/j. molonc.2015.02.003.

13. Ennour-Idrissi K, Maunsell E, Diorio C. Telomere Length and Breast Cancer Prognosis: a systematic review. Cancer Epidemiol Biomarkers Prev. 2017; 26:3-10. https://doi. org/10.1158/1055-9965.EPI-16-0343.

14. Chin K, de Solorzano CO, Knowles D, Jones A, Chou W, Rodriguez EG, Kuo WL, Ljung BM, Chew K, Myam bo K, Miranda M, Krig S, Garbe J, et al. In situ analyses of genome instability in breast cancer. Nat Genet. 2004; 36:984-8. https://doi.org/10.1038/ng1409.

15. Meeker AK, Argani P. Telomere shortening occurs early during breast tumorigenesis: a cause of chromosome destabilization underlying malignant transformation? J Mammary Gland Biol Neoplasia. 2004; 9:285-96. https:// doi.org/10.1023/B:JOMG.0000048775.04140.92.

16. Odagiri E, Kanda N, Jibiki K, Demura R, Aikawa E, Demura H. Reduction of telomeric length and c-erbB-2 gene amplification in human breast cancer, fibroadenoma, and gynecomastia. Relationship to histologic grade and clinical parameters. Cancer. 1994; 73:2978-84. https:// doi.org/10.1002/1097-0142(19940615)73:12<2978::AIDCNCR2820731215>3.0.CO;2-5. 
17. Tanaka H, Abe S, Huda N, Tu L, Beam MJ, Grimes B, Gilley D. Telomere fusions in early human breast carcinoma. Proc Natl Acad Sci U S A. 2012; 109:14098103. https://doi.org/10.1073/pnas.1120062109.

18. d'Adda di Fagagna F, Reaper PM, Clay-Farrace L, Fiegler H, Carr P, von Zglinicki T, Saretzki G, Carter NP, Jackson SP. A DNA damage checkpoint response in telomereinitiated senescence. Nature. 2003; 426:194-8. https://doi. org/10.1038/nature02118.

19. Takai H, Smogorzewska A, de Lange T. DNA damage foci at dysfunctional telomeres. Curr Biol. 2003; 13:1549-56. https://doi.org/10.1016/S0960-9822(03)00542-6.

20. Smogorzewska A, de Lange T. Different telomere damage signaling pathways in human and mouse cells. EMBO J. 2002; 21:4338-48. https://doi.org/10.1093/emboj/cdf433.

21. Fujita K, Horikawa I, Mondal AM, Jenkins LMM, Appella E, Vojtesek B, Bourdon JC, Lane DP, Harris CC. Positive feedback between p53 and TRF2 during telomere-damage signalling and cellular senescence. Nat Cell Biol. 2010; 12:1205-12. https://doi.org/10.1038/ncb2123.

22. van Steensel B, Smogorzewska A, de Lange T. TRF2 protects human telomeres from end-to-end fusions. Cell. 1998; 92:401-13. https://doi.org/10.1016/S0092-8674(00)80932-0.

23. Karlseder J, Broccoli D, Dai Y, Hardy S, de Lange T. p53- and ATM-dependent apoptosis induced by telomeres lacking TRF2. Science. 1999; 283:1321-5. https://doi. org/10.1126/science.283.5406.1321.

24. Karlseder J, Smogorzewska A, de Lange T. Senescence induced by altered telomere state, not telomere loss. Science. 2002; 295:2446-9. https://doi.org/10.1126/ science. 1069523.

25. Feuerhahn S, Chen LY, Luke B, Porro A. No DDRama at chromosome ends: TRF2 takes centre stage. Trends Biochem Sci. 2015; 40:275-85. https://doi.org/10.1016/j. tibs.2015.03.003.

26. Doksani Y, Wu JY, de Lange T, Zhuang X. Super-resolution fluorescence imaging of telomeres reveals TRF2-dependent T-loop formation. Cell. 2013; 155:345-56. https://doi. org/10.1016/j.cell.2013.09.048.

27. Denchi EL, de Lange T. Protection of telomeres through independent control of ATM and ATR by TRF2 and POT1. Nature. 2007; 448:1068-71. https://doi.org/10.1038/ nature 06065 .

28. Soule HD, Maloney TM, Wolman SR, Peterson WD, Brenz R, Mcgrath CM, Russo J, Pauley RJ, Jones RF, Brooks SC. Isolation and characterization of a spontaneously immortalized isolation and characterization of a spontaneously immortalized human breast. Cancer Res. 1990; 50:6075-86.

29. Rubis B, Holysz H, Gladych M, Toton E, Paszel A, Lisiak N, Kaczmarek M, Hofmann J, Rybczynska M. Telomerase downregulation induces proapoptotic genes expression and initializes breast cancer cells apoptosis followed by DNA fragmentation in a cell type dependent manner. Mol
Biol Rep. 2013; 40:4995-5004. https://doi.org/10.1007/ s11033-013-2600-9.

30. Listerman I, Sun J, Gazzaniga FS, Lukas JL, Blackburn EH. The major reverse transcriptase-incompetent splice variant of the human telomerase protein inhibits telomerase activity but protects from apoptosis. Cancer Res. 2013; 73:2817-28. https://doi.org/10.1158/0008-5472.CAN-12-3082.

31. Stampfer MR, Yaswen P. Culture models of human mammary epithelial cell transformation. J Mammary Gland Biol Neoplasia. 2000; 5:365-78. https://doi. org/10.1023/A:1009525827514.

32. Elenbaas B, Spirio L, Koerner F, Fleming MD, Zimonjic DB, Donaher JL, Popescu NC, Hahn WC, Weinberg RA. Human breast cancer cells generated by oncogenic transformation of primary mammary epithelial cells. Genes Dev. 2001; 15:5065. https://doi.org/10.1101/gad.828901.monly.

33. Lane DP, Simanis V, Bartsch R, Yewdell J, Gannon J, Mole S. Cellular targets for SV40 Large T-antigen. Proc R Soc London Ser B, Biol Sci. 1985; 226:25-42. https://doi. org/10.1098/rspb.1985.0077.

34. Huschtscha LI, Neumann AA, Noble JR, Reddel RR. Effects of Simian virus $40 \mathrm{~T}$-antigens on normal human mammary epithelial cells reveal evidence for spontaneous alterations in addition to loss of p16INK4a expression. Exp Cell Res. 2001; 265:125-34. https://doi.org/10.1006/excr.2001.5178.

35. Toouli CD, Huschtscha LI, Neumann AA, Noble JR, Colgin LM, Hukku B, Reddel RR. Comparison of human mammary epithelial cells immortalized by simian virus 40 T-Antigen or by the telomerase catalytic subunit. Oncogene. 2002; 21:128-39. https://doi.org/10.1038/sj/onc/1205014.

36. Farmer G, Bargonetti J, Zhu H, Friedman P, Prywes R, Prives C. Wild-type p53 activates transcription in vitro. Nature. 1992; 358:83-86. https://doi.org/10.1038/358083a0.

37. An P, Sáenz Robles MT, Pipas JM. Large T antigens of polyomaviruses: amazing molecular machines. Annu Rev Microbiol. 2012; 66:213-36. https://doi.org/10.1146/ annurev-micro-092611-150154.

38. Worsham MJ, Pals G, Schouten JP, Miller F, Tiwari N, Van Spaendonk R, Wolman SR. High-resolution mapping of molecular events associated with immortalization, transformation, and progression to breast cancer in the MCF10 model. Breast Cancer Res Treat. 2006; 96:177-86. https://doi.org/10.1007/s10549-005-9077-8.

39. Marella NV, Malyavantham KS, Wang J, Matsui S, Liang P, Berezney R. Cytogenetic and cDNA microarray expression analysis of MCF10 human breast cancer progression cell lines. Cancer Res. 2009; 69:5946-53. https://doi. org/10.1158/0008-5472.CAN-09-0420.

40. Wade MA, Sunter NJ, Fordham SE, Long A, Masic D, Russell LJ, Harrison CJ, Rand V, Elstob C, Bown N, Rowe $\mathrm{D}$, Lowe $\mathrm{C}$, Cuthbert $\mathrm{G}$, et al. C-MYC is a radiosensitive locus in human breast cells. Oncogene. 2015; 34:4985-94. https://doi.org/10.1038/onc.2014.427. 
41. Weiss MB, Vitolo MI, Mohseni M, Rosen DM, Denmeade SR, Park BH, Weber DJ, Bachman KE. Deletion of p53 in human mammary epithelial cells causes chromosomal instability and altered therapeutic response. Oncogene. 2010; 29:4715-24. https://doi.org/10.1038/onc.2010.220.

42. Ray FA, Meyne J, Kraemer PM. SV40 T antigen induced chromosomal changes reflect a process that is both clastogenic and aneuploidogenic and is ongoing throughout neoplastic progression of human fibroblasts. Mutat Res. 1992; 284:265-73. https://doi. org/10.1016/0027-5107(92)90011-P.

43. Genescà $\mathrm{A}$, Pampalona $\mathrm{J}$, Frías $\mathrm{C}$, Domínguez $\mathrm{D}$, Tusell L. Role of telomere dysfunction in genetic intratumor diversity. Adv Cancer Res. 2011; 112:11-41. https://doi. org/10.1016/B978-0-12-387688-1.00002-8.

44. Maciejowski J, Li Y, Bosco N, Campbell PJ, De Lange T. Chromothripsis and kataegis induced by telomere crisis. Cell. 2015; 163:1641-54. https://doi.org/10.1016/j. cell.2015.11.054.

45. Davoli T, Denchi EL, de Lange T. Persistent telomere damage induces bypass of mitosis and tetraploidy. Cell. 2010; 141:8193. https://doi.org/10.1016/j.cell.2010.01.031.

46. Pampalona J, Frías C, Genescà A, Tusell L. Progressive telomere dysfunction causes cytokinesis failure and leads to the accumulation of polyploid cells. PLoS Genet. 2012; 8:e1002679. https://doi.org/10.1371/journal.pgen.1002679.

47. Ahler E, Sullivan WJ, Cass A, Braas D, York AG, Bensinger SJ, Graeber TG, Christofk HR. Doxycycline Alters Metabolism and Proliferation of Human Cell Lines. PLoS One. 2013; 8:e64561. https://doi.org/10.1371/journal. pone.0064561.

48. Jacobs JJ, de Lange T. Significant role for p16INK4a in p53independent telomere-directed senescence. Curr Biol. 2004; 14:2302-8. https://doi.org/10.1016/j.cub.2004.12.025.

49. Pan MR, Peng G, Hungs WC, Lin SY. Monoubiquitination of $\mathrm{H} 2 \mathrm{AX}$ protein regulates DNA damage response signaling. J Biol Chem. 2011; 286:28599-607. https://doi. org/10.1074/jbc.M111.256297.

50. Boichuk S, Hu L, Hein J, Gjoerup OV. Multiple DNA damage signaling and repair pathways deregulated by Simian Virus 40 Large T antigen. J Virol. 2010; 84:800720. https://doi.org/10.1128/JVI.00334-10.

51. Kaul Z, Cesare AJ, Huschtscha LI, Neumann AA, Reddel RR. Five dysfunctional telomeres predict onset of senescence in human cells. EMBO Rep. 2011; 13:52-59. https://doi.org/10.1038/embor.2011.227.

52. Brenner AJ, Stampfer MR, Aldaz CM. Increased p16 expression with first senescence arrest in human mammary epithelial cells and extended growth capacity with p16 inactivation. Oncogene. 1998; 17:199-205. https://doi. org/10.1038/sj.onc.1201919.

53. Romanov SR, Kozakiewicz BK, Holst CR, Stampfer MR, Haupt LM, Tlsty TD. Normal human mammary epithelial cells spontaneously escape senescence and acquire genomic changes. Nature. 2001; 409:633-7. https://doi. org/10.1038/35054579.

54. Garbe JC, Holst CR, Bassett E, Tlsty T, Stampfer MR. Inactivation of $\mathrm{p} 53$ function in cultured human mammary epithelial cells turns the telomere-length dependent senescence barrier from agonescence into crisis. Cell Cycle. 2007; 6:1927-36. https://doi.org/10.4161/cc.6.15.4519.

55. Celli GB, de Lange T. DNA processing is not required for ATM-mediated telomere damage response after TRF2 deletion. Nat Cell Biol. 2005; 7:712-8. https://doi. org/10.1038/ncb1275.

56. Cesare AJ, Hayashi MT, Crabbe L, Karlseder J. The telomere deprotection response is functionally distinct from the genomic DNA damage response. Mol Cell. 2013; 51:141-55. https://doi.org/10.1016/j.molcel.2013.06.006.

57. Hayashi MT, Cesare AJ, Rivera T, Karlseder J. Cell death during crisis is mediated by mitotic telomere deprotection. Nature. 2015; 522:492-6. https://doi.org/10.1038/ nature 14513.

58. LaBarge MA, Garbe JC, Stampfer MR. Processing of human reduction mammoplasty and mastectomy tissues for cell culture. J Vis Exp. 2013; 71:e50011. https://doi. org/10.3791/50011.

59. Garbe JC, Bhattacharya S, Merchant B, Bassett E, Swisshelm K, Feiler HS, Wyrobek AJ, Stampfer MR. Molecular distinctions between stasis and telomere attrition senescence barriers shown by long-term culture of normal human mammary epithelial cells. Cancer Res. 2009; 69:7557-68. https://doi.org/10.1158/0008-5472.CAN-09-0270.

60. Cesare AJ, Heaphy CM, O'Sullivan RJ. Visualization of telomere integrity and function in vitro and in vivo using immunofluorescence techniques. Curr Protoc Cytom. 2015; 73:12.40.1-31. https://doi.org/10.1002/0471142956. cy $1240 \mathrm{~s} 73$. 